\title{
The Female Detective
}

\section{Agent of (Gender)Justice? Exploring Female Detective Agency and Investigating}

Female detectives or investigators occupy a lawful and visible position within the hegemonic patriarchal system. ${ }^{1}$ As professionals, the detectives discussed here are employed by either the police or the media and are given authority to work on behalf of these still mostly male-dominated institutions. Female detection thus constitutes a claim to power and equality within these institutions. Licensed and empowered as these women are, they are also compromised to varying degrees as agents of the very institution, of the very law that marginalises them. In this context, the detective's quest for justice must necessarily include her own subject position and agency, as well as the gender and racial implications of the criminal cases that she solves. The female detective's scope for resistant agency will influence what truths she establishes and what kind of justice she is thereby able to serve.

The female detectives discussed here are all serial heroines of women writers, in series that are all still in their early stages. They are police detective Persy Jonas, who features in Michéle Rowe's novels What Hidden Lies (2013) and Hour of Darkness (2015); Vee Johnson, who is Hawa Jande Golakai's journalist protagonist in The Lazarus Effect (2011) and The Score (2015); and Maggie Cloete, Charlotte Otter's crime reporter in Balthasar's Gift (2014) and Karkloof Blue (2016). My aim is to explore the gender performances of these female investigators, who come from diverse social and ethnic backgrounds. How do they navigate the tensions they are subjected to as female professionals in male-dominated institutions? Do they enact or subvert the detective agency that they are granted? How do they, as gendered and raced agents of the law, resist and negotiate the law's construction of gender and race? These questions touch on what has been at the heart of the feminist scholarly debate surrounding this figure: her political effectiveness as a feminist resistant agent.

1 The terms "detective" and "investigator" are used interchangeably and regardless of institutional affiliation here. 
I will argue that Persy, Vee and Maggie are not free of conflicting pressures, but that they negotiate them in creative and often successful ways.

Racial and gender politics is also a factor in determining the crimes and victims the detectives attend to, the truths they uncover and the kind of justice they thereby administer. This gives rise to a second set of questions. What aspects of the South African real are subject to female investigation? What kinds of violations do female detectives stumble upon, and where does the site of interrogation lie? What spaces for justice do they open up? What notions of justice do they enforce and restore? What alternatives do they envisage? Twenty years into democracy, these questions are still relevant in South Africa. The formal equality granted to South African women under the constitution remains incomplete in the lived reality of many women, especially economically disadvantaged women of colour. South African feminist legal scholars argue that, to some extent, the gendered nature of the law itself is to blame for this discrepancy. They therefore aim to highlight "the problems which the ostensible neutrality and objectivity of the law hold for women" (Albertyn and Bonthuys 2007, 2). Catherine Albertyn maintains that actual, substantive equality "encompasses some notion of remedial or redistributive justice $[\ldots]$ " $(2007,94)$. Arguably, the fictional detectives examined here not only operate as agents of the established criminal justice system, but adhere to forms of so-called "restorative justice", which is victim based and relies on remedial measures. By working for more equality and striving to remedy the law's masculine discourse, they are able to find different versions of "truth" and justice.

The Female Detective in British and American Crime Fiction: Legacies and Scholarly Debates

The fictional female sleuth has always been part of the history of crime writing (Gavin 2010, 258, Worthington 2011, 111). And yet, "[w] hether the detective is male or female, straight or gay, she or he always exists in negotiation with a series of long-established masculine codes" (Plain 2001, 11). For Kathleen Gregory Klein, the female detective is "a contradiction in terms" (1988, 225). She views fictional women detectives as compromised on the grounds that the genre portrays them either as inadequate women or as inadequate detectives (225). What is at stake here is the potential and efficacy of the female detective as a feminist resistant agent. There is disagreement about whether her position within the system allows her to resist that system or, as Gill Plain puts it, "whether changes in the subjectivity of the detective can effect a more fundamental challenge to wider socio-political structures" (2001, 88). The masculine codes to which Plain refers are reflected in the genre's 
preference for individualism - as embodied in the lone detective hero - and its emphasis on knowledge, logic, rationality and, more recently, forensic science (Worthington 2011, 109). It is thus not obvious at first why female writers would strategically adopt the genre for feminist ends. And yet they have done so - and with verve - especially in the context of women's demands for access to male-dominated areas. The late 1970s and early 1980s saw the advent of politicised feminist crime fiction, with pioneering writers such as Marcia Muller, Sara Paretsky, Sue Grafton and Liza Cody (Gavin 2010, 264-265, see also Munt 1994, 27, Kinsman 2010, 153, Knight 2010, 167). Adrienne Gavin considers "[ $\mathrm{t}$ ]aking detection in new overtly feminist directions" to be as much "a feminist response to male hard-boiled writing" as a continuation of "previous female detection" (2010, 265). In any case, it marked a significant change in crime writing. Stephen Knight maintains that "feminist crime writers have changed the face of the genre enormously" $(2010,165)$ and finds that Marcia Muller created "an authoritative new model of the detective," thus making "an impact like Doyle and Hammett" (168). As Heather Worthington puts it: "In the wake of the feminist movement, the fully formed modern female, or even feminist, detective comes into being" $(2011,48)$. It is important to note that the genre's feminist impetus has been channelled mainly through the figure of the female detective or private eye. The impulse behind feminist detective narratives, the "desire to translate passivity into action" (Plain 2001, 159) and to explore "the thorny issue of the relationship between woman's victimization and woman's agency" (Walton 2013, 23), has been realised in the female detective figure.

Crime fiction does not lend itself to feminist engagement for writers and their detective heroines alone: feminist scholars, too, have taken an avid interest in the genre. As Plain highlights, "the genre's profound investment in dynamics of power," which has inevitably resulted in the incorporation of "discourses of gender and sexuality," makes it a "prime site for the development of feminist readings" (2001, 8). Indeed, the suitability and effectiveness of the figure of the female detective for political, revisionist purposes has become a subject of heated debate. Prominent among those who accord the genre feminist potential are Priscilla Walton and Manina Jones. Their seminal work Detective Agency: Women Rewriting the Hard-Boiled Tradition (1999) follows in the footsteps of earlier critics such as Maureen Reddy (1988) and Sally Munt (1994). According to Walton and Jones, writing the detective figure as female allows for an alternative positioning of female characters. This equates to a recasting of the traditional role of woman as the generic outlaw (for example, in the figure of the femme fatale) and functions to destabilise the masculine codes of the genre: 
While the traditional hard-boiled novel demonized and punished the female character who contravened conventional ideas about feminine submissiveness by desiring and acting, the feminist hard-boiled novel makes that role a heroic one $[\ldots]$. Working through the conventions of the genre to subvert some of its most powerful traditions, both authors and characters of the "tough gal" novels make a kind of feminist "outlaw agency" possible. 1999, 195

In Walton's and Jones's view, this act of rewriting and empowering the formerly outlawed female constitutes a "reverse discourse" in the Foucauldian sense; it explores "positions of resistance and agency that were offered by previous practices but that were inaccessible to women" (93). They contend that "these texts can both inscribe an empowered female subject and rework the conventions of subjectivity that make that position problematic" (113). What they also find is that novels premised on the female detective counter "the utopian notion that one can work outside the patriarchal structure of Western society [...]" (102-103). In other words, if the female detective is necessarily implicated in the socio-political status quo, the novels enable a playing out of possibilities and limits with regard to her resistant agency without naively assuming that gendered action can occur beyond normative constraints.

However, other critics do not regard detective agency as feminist agency. Teresa L. Ebert, for example, calls the female detective an agent of the phallus, a "surrogate agent of patriarchy" $(1992,16)$. The female detective may achieve equality and thus enjoy improved conditions within patriarchy, but she does not challenge it (14). Ebert rejects the notion that reform can be brought about from within the system.

Detecting, in short, is a disciplinary practice that enlists individuals - regardless of their "gender" (anatomy) - as agents of phallic authority who act to restore patriarchal order and hegemony. Thus, women who engage in the ideologically encoded practice of detecting (whether as "detectives" or readers) do not indicate a significant alteration of the sexual politics of the genre but rather an expansion of the patriarchal agency and authority - often in spite of the women's own intentions.

13

Kathleen Gregory Klein takes a similar view. She describes the female detective as "a contradiction in terms" $(1988,225)$ and sees the authors of crime fiction as reinforcing patriarchal ideology (223). For Klein, the term "woman detective" is an oxymoron: "[i]f female, then not detective; if detective, then not really female" $(1995,174)$. Nevertheless, she identifies a possible way 
out of this impasse. In Klein's view, it is the lesbian detective who has truly feminist-disruptive potential, for as a sexual "deviant" her position "approaches the positionality of a criminal" (177). This line of argument is developed by Plain, who rereads male and female-authored crime fiction of the twentieth century through the critical lens of gender. She contends that the feminist project of the heterosexual female detective is a failure due to the inevitable complicity of heterosexual desire with patriarchy $(2001,163,206)$. True subversion, according to Plain, lies in the lesbian detective and in the female detective's conflation with the serial killer. The latter she finds exemplified in Thomas Harris's The Silence of the Lambs, with Clarice Starling as a detective who "identifies the killer through proximity and similarity, rather than from a comfortable analytic or moral distance" $(226-227)$. Yet, such subversion, for Plain, comes at the cost of generic dissolution: "What began as a mode of restoring order - a series of fictional fantasies that envisaged agency and order even in the midst of chaos - has evolved into a narrative mode that embraces exactly that which it initially sought to exclude. This attempt to contain the other through incorporation and inclusion has led, however, to dilution" (247). When the detective becomes "criminal" - be it through her sexuality or through her proximity to the serial killer - she constitutes not only a rupture of the system, but a crisis of the genre (221-222). As Plain points out, it is "impossible to resolve the competing claims for the [female] detective's agency or impotence" (89) in generalised terms. For this reason, it is important to consider not just the detective's subject position, but her mission in the specific context of South Africa.

\subsection{Female Investigating As Truth-Finding in South Africa}

Any detective's main duty is truth-finding. It is what he or she is both authorised and required to do in the interest of securing justice for the victim. However, this ostensibly simple directive is complicated by its entanglement in contexts where "truth" has been hijacked to preferred social ends. In reaction to the biases and prejudices that shaped "truth" under apartheid, in the early years of South African democracy truth-finding and truth-telling were instrumental in the country's transition to a more just dispensation. This was reflected in the very name of the institution mandated to facilitate it: the Truth and Reconciliation Commission. Pertinent here is the observation by Walton and Jones that, since the beginning of the American hard-boiled tradition, the detective's task has shifted from merely identifying the individual criminal to shedding light on the reasons behind the crime. Quoting Raymond Chandler, they emphasise that the detective's quest for "truth" involves "what the hell went on rather than who done it" (1999, 209). They argue that women writers of detective fiction have extended Chandler's tenet from locating the reasons " 'in character and relationship' to the 
ideological raison d'être of systemic crimes," on the basis that "'who done it' often turns out to be a societal entity" (209). The mandate of the TRC reveals a similar multifaceted understanding of the truth-finding process. In the first volume of its report, the TRC declared that its aim was to establish

as complete a picture as possible of the causes, nature and extent of the gross violations of human rights which were committed during the period from 1 March 196o to the cut-off date [10 May 1994], including the antecedents, circumstances, factors and context of such violations, as well as the perspectives of the victims and the motives and perspectives of the persons responsible for the commission of the violations.

POSEL 2OO2, 147

As Deborah Posel notes, “The TRC's truth-telling mandate was partly descriptive (what had happened, when, who had done it), partly explanatory (why, with regard to structural, institutional causes as well as motives and perspectives of relevant historical actors)" (153). Given that the fictional detectives examined in this study display a strong concern with past crimes, their quest for the "truth" needs to be viewed not only against the background of traditions within the crime genre more generally, but in the light of the TRC's work in South Africa itself. In part one, I discussed the many reservations that have been expressed by South African women about the "truth" uncovered by the тRC. Their critique of the TRC's practices will also inform my reading of the female detective figure. In addition, I will draw on Posel's analysis of the kinds of truth (and their power) that the TRC revealed, and constructed, as well as South African and international feminist research into the law, the criminal justice process and inclusive models of justice.

In South African crime fiction, there is a long tradition of female investigators that goes back as far as June Drummond and her elderly amateur sleuth Nan. Nan, the protagonist of Drummond's 1959 novel The Black Unicorn, can be regarded as an influential precursor of contemporary South African fictional female detectives and investigators (Pretorius 2014) . Another figure worth mentioning is Gillian Slovo's detective heroine Kate Baeier, who first appears in the 1984 thriller Morbid Symptoms. Although Slovo's detective is based in London, the Kate Baeier series has a distinctly South African ring and provides a means for Slovo to explore past secrets and silences in an attempt to produce a new history (Braude 1996, 43-52). These concerns persist in the post-transitional crime fiction boom that has brought forth an ever-increasing number of female detectives, notably Margie Orford's Clare Hart, Angela Makholwa's Lucy Khambule, Jassy Mackenzie's Jade de Jong, Tracy Gilpin's Dunai Marks, Joanne 
Hichens's Rae Valentine, Penny Lorimer's Nix Mniki, Wessel Ebersohn's Abigail Bukula and Sally Andrew's Tannie Maria. ${ }^{2}$ Many of these characters are rooted in the genre tradition of the feisty, tough, hard-boiled heroine. The three detectives I will discuss are among the most recent additions to the list. They were chosen because, together with their authors, they represent a range of new and different perspectives - domestic, immigrant and diasporic - as well as diverse, even conflicting, female subject positions. Around twenty years into democracy, they continue the South African tradition of female investigators while adding decidedly new twists and drawing attention to issues of crime, truth and justice in South Africa in new ways.

\section{Not That Kind of Cop: Michéle Rowe's Detective Constable Persy Jonas}

All these years I felt like a rookie, looked up to Tucker and oldschool career cops, and tried to follow in their hardass footsteps. But I'm not that kind of cop.

PERSY in Hour of Darkness (338)

This chapter sets out to investigate precisely what kind of cop Persy Jonas, the protagonist in Michéle Rowe's detective novels What Hidden Lies (2013b) and Hour of Darkness (2015), is. Persy's difference is made obvious to the reader in several ways long before Persy herself becomes aware of it at the end of the second novel. As a young, bespectacled woman of slight build, she is at odds with the sexist macho mentality of the South African Police Service. Representing and enforcing state power as well as the law, Persy, the policewoman, occupies an uneasy position not only in relation to her corrupt colleagues in the police, but within her own Cape Coloured community, which has been criminalised by both the racist politics of the apartheid regime in the past and the precarious economic circumstances of the present. As I will show, Persy's impossible professional position both compromises her detective agency and requires her to navigate and to subvert the system in creative and alternative ways. By doing so, she is able to open up a space for agonistic solidarity, a significant form of agency, in her collaboration with her investigative partner Marge Labuschagne. I will explore the implications of this both for Persy's criminal

2 For a comprehensive list that includes female sidekicks as well as female detectives in fiction by South African authors writing in languages other than English, see Mike Nicol's Crime Beat blog (http://crimebeat.bookslive.co.za/whos-who-of-south-african-crime-writing/). 
investigations and for the kind of justice that she is able to serve. Critical work on the TRC as well as South African and international feminist legal scholarship will undergird my reading and assessment of Persy's endeavours to find the "truth" and restore justice.

A graphic artist, production designer for films and TV commercials and award-winning scriptwriter, Michéle Rowe came to crime fiction relatively late in her career. ${ }^{3}$ She arrived on the scene with fanfare by immediately winning the much coveted Crime Writers' Association Debut Dagger Award in 2011 for the opening chapters of What Hidden Lies (Rowe 2017, par. 7). Hour of Darkness is her second Persy Jonas novel in what is planned as a trilogy, to be rounded off with Before His Time (Rowe 2016, par. 18). ${ }^{4}$ Her fiction has also been translated into French and German. Rowe lives in South Africa, where she was born and educated (Rowe 2013a, par. 1, 5, Fourie 2013, par. 1). From Nicol we learn that "[s] he has great-grandparents who came from Mauritius and whose children crossed over to the White side during the time of the pencil test," i.e. during the height of apartheid, when a pencil inserted into especially curly hair was often used to determine racial categorisation $(2015 \mathrm{a}, 18)$.

The woman who will become Detective Constable Persy Jonas makes her first appearance as a girl of around seven in the opening scene of What Hidden Lies, which is set on the Cape Peninsula. In that haunting scene, we accompany Persy and her childhood friend Sean Dollery into the woods on the slopes of Chapman's Peak, where they manage to shake off Persy's younger brother Clyde, who has run after them. However, what was intended as a childish ploy by Persy to elude her annoying sibling leads directly to a tragic death, for moments later Clyde is buried alive when the nearby open kaolin mine is filled in. Twenty years later, Persy's first case inadvertently takes her back to this repressed childhood trauma as she investigates the murder of Andrew Sherwood, a local school teacher and alleged paedophile. The same past events have a bearing not only on Persy, but on her fellow investigator, retired criminal psychologist Marge Labuschagne. Persy and Marge first relate with great reluctance and hostility, but eventually they begin to bond. Their friendship deepens in the course of the second novel, Hour of Darkness, which is set

3 As detailed on her personal website, Rowe's projects have won her an Oscar documentary and International Emmy nomination, a Mail \& Guardian Short Films Prize, a Special Jury Award at Skip City International (Japan), a Banff World TV Award (Canada), a SAFTA (South African Film and Television Award) and the Andrew Murray - Desmond Tutu Prize (Rowe 2017, par. 4).

4 In an earlier interview, Rowe gives the title of her third novel as Before Her Time (Rowe 2013a, par. 16). 
in the southern suburbs of Cape Town and features a case of three missing women: Severine, teenage daughter of the affluent but emotionally damaged Hamilton-Langford family, Annette Petroussis, their neighbour, and Mandisa, teenage daughter of Nosapho Dasheka, the domestic worker for Severine's family. Land claims, some reaching far back in time, form the backdrop of the novel. As so often in South African crime fiction, the criminal investigation involves a review of the past and the grip that it has on the present. Later I will examine these pressures, together with Persy's dual mission to establish "truth" and justice respectively. First, however, I will explore the difficulties of Persy's position as an agent working for and in a social and professional system that restrains and subjugates her, and identify the possibilities for resistant political agency sketched out in the novels.

\subsection{Persy Jonas: Female Detective Agency Compromised}

Persy's full name, Persephone, was chosen for her by her grandfather - her Poppa (Rowe 2013b, 59, 176). Like her namesake in Greek mythology, she inhabits different worlds with conflicting pressures and is associated with dilemma and compromise. ${ }^{5}$ Because the dilemmas that Persy faces fall into three categories - gender, sexuality and race - I will discuss them from a gender-race intersectional perspective.

The first of these dilemmas relates to gender. It is the typical predicament of the female detective in crime fiction, as well as of real women working in the South African Police Service (SAPS). As a junior member of the SAPS, Persy presents as the enterprising, tough, determined cop and has full detective agency. She is the equal, if not the superior, of her male colleagues in any situation. She boasts impeccable credentials and is very smart $(2013 \mathrm{~b}, 264,2015,120)$. Not only is she highly ambitious $(2013 \mathrm{~b}, 38,56,2015,73)$, she is also admired for her guts $(2013 \mathrm{~b}, 288)$. Persy asserts her authority as a police officer despite the fact that she does not look the part. Marge "could hardly imagine a less likely detective": Persy reminded her of her "bookish, lesbian" Trotskyite university students from the 1980s (2013b, 34). Persy's dreadlocks and "God Bless Africa" T-shirt variously evoke admiration, humour and ridicule $\left(2013 \mathrm{~b}, 213^{-214}\right.$,

5 In Greek mythology, Persephone is the daughter of Zeus and Demeter. When Persephone is kidnapped by Hades to become his wife and queen of the underworld, her enraged mother Demeter demands that she be returned. Mediating between Demeter and Hades, Zeus finally decides that Persephone should live with her mother for eight months a year and with her husband for four months. Demeter responds by allowing no crops to grow in the four months during which she is deprived of her daughter, thus creating the winter season (De Crescenzo 1998, 109-114, Morford 2016). 
$2015,75,203)$. Still, Persy functions as the cop. She bangs on suspects' doors, shouting "'SAPS! Open up!" (2013b, 7); she forcefully and effectively stops an illegal dog fight and rescues Marge's dog Bongo (2013b, 186); she orders criminals to drop their weapons and shoots them when they fail to comply $(2013 \mathrm{~b}$, 286). When questioning suspects, whether it be in their mansions, at the crime scene or in the police interrogation room, Persy is unfazed by their social class or skin colour (2013b, 184, 304-305, 2015, 175, 180-185, 207-208). In cases where she sees her investigation being stalled or hindered, she repeatedly disregards police hierarchies $(2013 \mathrm{~b}, 27,91,98,2015,216,247,290)$, spurns control by authority and becomes the maverick cop (2013b, 6, 106-107, 2015, 238-243). What is more, she refuses to be blackmailed by criminals and is not corrupt, nor is she prepared to turn a blind eye to corruption among her fellow police officers (2015, e.g. 278-279). In other words, she emulates and equals the personality and agency of the genre-typical male detective: heroic, autonomous, individually non-conformist and relatively violent. She thereby claims and fills the traditionally masculine space of the detective.

And yet this space, the institution of the police, also vehemently opposes her. She is repeatedly reined in by her superiors and colleagues alike. She gets reprimanded for insubordination $(2013 \mathrm{~b}, 146,2015,290)$, is criticised for turning down male protection $(2013 \mathrm{~b}, 189,219,287)$ and is allocated typically female jobs such as looking after the young sons of the missing Annette (2015, 36-37). Persy is quick to notice and criticise the gender bias inherent in this treatment, as when she indignantly reminds her superior Ren Tucker, "I'm a detective, not a fucking babysitter'" $(2015,37)$. However, because she seldom does so openly, her criticisms remain ineffective. Another female officer, Dina Martinez, although much further up the police hierarchy, is subjected to the same gender bias as Persy. As Persy notes, "You did not make Captain heading up a detective unit unless you were tough, and Dina was tough. If Dina were a man, it would be cause for admiration. As it was, she was very unpopular among the male cops" $(2015,118)$. Time and again Persy also has to deal with misogyny and sexual harassment from her male colleagues and with insinuations that she has advanced this far in the force only because she is a woman $(2013 \mathrm{~b}, 43,143$, 150, 2015, 73, 180-181). As combative as Persy is, she does not challenge these manifestations of the fact that the police service remains a male institution. Mostly, she is silent, and thus appears to be silenced. When Tucker mocks her saying, "'[f]emales don't last in this job", Persy does not rise to the bait, recognising that "there was no point. At least he'd said to her face what most of her male colleagues only thought. His dismissal of her only strengthened her resolve to prove him wrong" $(2015,70)$. Similarly, while she retaliates verbally when her colleague Mhlabeni issues sexual threats, she resolves that "[i]t was 
no use complaining about intimidation. Her life would not be worth living if she ran crying to Titus." Instead, "she had to control herself. That's all she had, her ability to appear impervious, no matter what" (2013b, 43). In Persy, Rowe gives us a familiar female figure uneasily emplaced within male-oriented, patriarchal professional structures. As Hans Bertens and Theo D'haen note in relation to female professionals in American crime fiction, "[b]ringing women into the police departments almost invariably made the institution show its true, thoroughly masculinist colors and thereby undermined its supposed neutrality" $(2001,14)$. Rowe must be credited for making this bias visible in her crime fiction.

It is a bias that extends beyond the fictional: Rowe is reflecting the experiences of actual policewomen in South Africa. As Theresa Ulicki's recent work on gender equity and sexual harassment in the South African Police Service in Gauteng province demonstrates, female police officers routinely face a dilemma similar to Persy's. For example, even though in 2008 the SAPs prided itself on the fact that nearly 21 percent of its officer complement were female (Ulicki 2011, 97) - a figure higher than that for most police services across the world - and even though the SAPS drafted a sexual harassment policy as far back as 1998, in 2011 the service was still rife with systemic gender discrimination. According to Ulicki, this discrimination manifests itself mainly in the form of sexual harassment and factors that deter policewomen from reporting such behaviour:

They have insider knowledge of how civilian women who report rape, sexual assault and domestic violence are treated by police. They fear a backlash, particularly by male colleagues, who make up the vast majority of their co-workers. There are few women in leadership positions to whom they can report abuse. The grievance process itself is flawed: the chance of disciplinary action against an abuser is low, the process lacks confidentiality and is very lengthy. Finally, as some women have discovered by reporting sexual harassment, standing up for your rights can result in other forms of harassment and a negative work environment.

$110-111$

Policewomen adopt protective strategies of acceptance and denial (109), while the systematically ingrained resistance of the male institution persists. Ulicki concludes that a focus on formal equality issues has a limited impact, as "the underlying systemic causes of gender inequity" remain untouched (114). In Rowe's crime writing, the gender bias of the South African Police Service is brought to light through Persy. Rowe exposes, yet at the same time fictionally 
perpetuates, the discrimination against policewomen. Persy's male colleagues are not held accountable for their abusive behaviour. By letting her protagonist seem to be subdued by the displays of male power, it can be argued that the female author not only proves them to be efficient at silencing women, but becomes complicit in the very practice of female effacement herself. In the long run, Persy's resolutions to work harder, to disprove the men, to appear unaffected, emerge as ineffective strategies. Indeed, at the end of the second novel, the policing institution seems to have successfully evicted her, since Persy is put on indefinite leave (Rowe 2015, 340). According to the masculine logic of the police, she is defeated, her detective agency is thwarted. For the police to become more gender inclusive, they would have to punish gender discrimination on a systemic level, as Ulicki's work shows. While in theory crime fiction could be one of the places to imagine this, Rowe's detective novels refrain from doing so.

Sexuality (and sexual orientation) comprises another arena for dilemma. Persy is androgynous in appearance (Rowe 2013b, 27), but clearly heterosexual. These factors awkwardly intersect, such that she appears to blur boundaries while at the same time conforming. In Hour of Darkness, she has an intense, disastrous sexual relationship with her immediate superior, Ren Tucker:

Persy had found him utterly compelling from the first moment she'd fixed eyes on him. Now [...] Persy thought about how sleeping with Tucker was about the worst idea she could have come up with - considering that he was white, head of the four squads of detectives at the station, and in the middle of a messy separation from his wife - and Persy's boss - Captain Dina Martinez, with whom he had three kids.

$2015,28-29$

In Hour of Darkness, there is a heavy emphasis on Persy's sexuality $(71,83,141$, $187,260-261)$. Insofar as her sexuality is portrayed as autonomous, with her desiring Tucker as much as he desires her, their relationship seems to be a successful, democratic rewriting of the racist South African script that heavily criminalised interracial relationships in the past. ${ }^{6}$ Yet Persy's desire and sexual agency are also represented as debilitating, which is problematic from a racially critical perspective. The disastrous implications of her relationship with Tucker can be intuited from the beginning (and are even expressly articulated

6 In Rowe's novels, equal interracial relationships - which are still far from being the norm in South Africa - are also tentatively imagined, though not (yet) realised between Persy and her Black colleague Dizu (2013b, 6o), and between Persy and Marge's White son Will (2015, 129-130). 
by Persy), and it soon becomes clear that Persy will be the one to pay the price. Not only does she depend on Tucker in their unequal professional relationship, but there is an increasing difference in their emotional goals, with Persy (as in the habituated gender economies of conventional romance) longing for more intimate affective attachment than does the male partner (190). What she has sensed all along then proceeds to happen: Tucker gives in to outside pressure and lets her down $(242,274,333)$. The novel hints at the fact that it will take a different kind of masculinity from the hegemonic machismo that Tucker embodies for an interracial relationship to work and to be truly equal. However, this suggestion is undermined by the way in which Persy's relationship with Tucker and her sexuality as such corner her on several levels. Far from being positive, liberating or even empowering, Persy's sexuality is portrayed as anomalous, even slightly pathological, as no more than a dubious coping strategy in moments of psychic distress. Sex, for Persy, is part of her "breakouts" (2013b, 182), serving to blunt her panic and temporarily drive out her demons $(2015,142)$. Without fail, sex leaves her full of remorse and selfloathing, feeling sick, confused, unsettled and wound up, even guilty $(2013 \mathrm{~b}$, $182,2015,139,142,164,187,263$ ). Apart from this, whenever she gives in to her desire, she feels that " $[t]$ he acorn does not fall far from the tree" $(2015,140$, see also 2013b, 182-183), fearing that she is following in her mother's footsteps. Sexual libertinism, paired with alcohol addiction, have been painted by Persy's Poppa as the source of her mother's problems. He invariably describes her to Persy as debauching in shebeens, drinking and sleeping around (2013b, 178, 182-183, 2015, 140), so that Persy thinks of her as "a slut and a drinker and a bad mother" (2015, 334).

Rowe's depiction of sexuality as the source of much trouble for both Persy and her mother must be understood in the context of how the sexuality of women of colour has been demonised. A wealth of research has explored the ways in which conceptualisations of the sexuality of women of colour as pathological and degenerate have been deployed in the service of the patriarchal, imperial project, masking a desire for control and power (Lewis 2011, 202203). The famous case of Sarah Baartman is just one example of this. Drawing on the work of Pumla Gqola, Lewis points out that control is "anchored in discursive representations of the sexualised and degenerate female body, a body that threatens to pollute or weaken the 'healthy' national body politic" (206). Rowe's depiction of Persy's and her mother's sexuality serves to reinscribe rather than to expose this racial and gendered script. ${ }^{7}$

7 For a much more positive depiction of Black female sexuality, see Hawa Jande Golakai's detective protagonist Vee. 
In What Hidden Lies, Persy's sexual encounter with a random man whom she meets in a bar is also problematic for its celebration of male dominance. Persy is on the lookout for a sexual partner, but, once she has identified the object of her desire, she actively encourages him to play the game of conquest: "The male animal. Trawling the water holes looking for prey. Fine, let him think he was the predator. [...] He was a crap [pool] player but she let him beat her. [...] Raoul leaned over her, pressing into her back ..." (Rowe 2013b, 180). Here, Persy asserts her sexual agency as she activates and then complies with the masculine code, both doing and undoing it. Moreover, she appears to celebrate and thus condone not only phallocentrism, but rape culture. Bell Hooks argues provocatively that

one major obstacle preventing us from transforming rape culture is that heterosexual women have not unlearned a heterosexist-based "eroticism" that constructs desire in such a way that many of us can only respond erotically to male behaviour that has already been coded as masculine within the sexist framework.

1994, 131

According to Hooks, if we want to oppose rape culture, we need to shape "our eroticism in ways that repudiate phallocentrism" (133). ${ }^{8}$ In this vein, one could read Persy's sexual behaviour as potentially complicit with male violence. In addition, Persy's sexuality and sexual agency place her in a professional quandary, thereby echoing Gill Plain's contention about the heterosexual female detective. For Plain, the feminist potential of the heterosexual female detective is flawed due to the complicity of heterosexual desire with patriarchy (2001, 163, 206). At the end of Hour of Darkness, Persy finds her career and future detective agency severely compromised by her sexuality. When Ren tries to reconnect with her, she retorts angrily, "Don't confuse fucking me in bed with fucking me over at work" (Rowe 2015, 163), yet this is precisely what happens, albeit indirectly. Their affair is abruptly curtailed when Persy and Tucker receive contract killer Fred Splinters's email with an attachment that shows them having sex in a car (276). Splinters's blackmail (commissioned by Ricardo Heinrich) works its effect on Tucker: he is afraid and wants to drop the Petroussis case. However, it has the contrary effect on Persy, who is determined to find out who is behind it and will not be intimidated. She asks Tucker to hand the case over to her (278-279). When he refuses, Persy not only starts to suspect Tucker - a

8 For a similar argument by Jewkes and Morrell (2010), see my discussion of Black Widow Society. 
man she has always adored as a straight cop - of being corruptible, but decides to continue the investigation on her own, unauthorised. With the support of her colleague Dizu and the psychologist Marge, she manages to link and solve the mysteries of the three missing women, but promptly faces Tucker's disapproval. He accuses Persy of insubordination on the Petroussis case (338) and asks Martinez to send her on indefinite leave (333) while the matter is under investigation. Although Persy retains the moral high ground and, in more ways than one, outgrows Tucker, she is compromised professionally. Her career now depends on whether or not Tucker takes the case against her further (340). All is not lost, but for the time being Persy is banished from the detective scene.

On race, too, Persy faces a series of predicaments. Like Sheemina February, as a Coloured person she occupies position that has been both empowered and marginalised in the historical South African racial hierarchy. As outlined previously, the position of Coloureds in between the powerful and the powerless has resulted in negative stereotyping of the community as untrustworthy by Black people and as manipulative by White. This is reflected in Rowe's novels when Persy's Black colleague Mhlabeni views her "as a betrayer, a snitch" (2013b, 25), as well as when the White Tucker calls his Coloured wife "a manipulative bitch" $(2015,163)$. Persy's own view as a Coloured person is that she is "torn between white and black interests," with nobody really representing Coloureds' interests $(2013 \mathrm{~b}, 134)$. Consider also her rage at being painted "as some kind of reactionary coconut enslaved to the witbaas" $(2015,150)$ by Heinrich. What Rowe does not unpack, however, are the links between Coloured subjectivity and shame. Persy recounts how much she envied her cousin's straight hair as a child. "It was shameful to have kroeshare, ${ }^{9}$ proof of your African blood" (2015, 106). Contract killer Fred Splinters taps into this by making sure that Natasha, his partner and probably Persy's mother, has "her hair blow-dried dead straight" as well as highlighted, since he "hated that natural bushy look she'd had when he met her. Now she looked classy, to go along with her new life - no more hiked-up skirts and low-cut tops" $(2015,67)$. What is being reinscribed here is the association between so-called Coloured hair, shame and female sexuality. Erasmus calls this a mechanism for "creating a stigma of shame around those of 'mixed' descent" (2001, 18). Zoë Wicomb identifies the colonial roots of "coloured shame" as "shame for our origins of slavery, shame for the miscegenation, and shame, as colonial racism became institutionalized, for being black" $(1998,100)$. As she points out, Coloured people attempted to erase their "shameful" origins by assuming European names. As a consequence, they

9 "Kroeshare" is Afrikaans for curly hair. 
"have lost all knowledge of [their] Xhosa, Indonesian, East African, or Khoi origins" (1998, 100). Constructing the colonial encounters that formed Coloured identities as unilaterally shameful was thus a complex mechanism of sociohistorical control. ${ }^{10}$ Persy's quasi orphan status, the loss of her father, mother and brother and, eventually, also of Poppa $(2015,143)$, could be said to re-enact the loss of origins associated with Coloured subjectivity. Insofar as her curly hair as a child and the fact that she is having a sexual relationship with her White boss Tucker in the present evoke feelings of shame in Persy $(2015,34)$, these old colonial controlling mechanisms continue to operate. They are internalised by Persy and remain unchecked by the narrative arc of the novel.

In contrast, Rowe's portrait of Persy is highly successful in exposing the direct and lingering effects on her life, especially as a woman, of the apartheid policy of forced removals. Persy muses on how forced removals back then created "[d] ormitory towns filled with labour that travelled to the white areas to work, and then back to the hellholes at night. Not much had changed even though the act had been abolished more than twenty years ago" (2013b, 89). This lack of change is exemplified by her own long, laborious and dangerous journey to work and back every day. Being able to afford neither a car nor a flat of her own, in What Hidden Lies Persy depends on getting rides across the peninsula from colleagues and her violent cousin Donny, who is also her landlord. This exposes her to the latter's drug-induced violence and drunk driving - and on two occasions nearly gets her killed (43-44, 84, 201-204, 283-285). Here, Rowe must be given credit for showing an awareness of the ways in which a woman's racial and class background can leave her vulnerable to structural violence.

Persy's position as a Coloured woman in South Africa is already ambiguous, but as a Coloured female police officer she moves into another collision zone. In this role, she qualifies for the label of "ethnic" or "postcolonial detective". Using Homi Bhabha's notion of liminality, Ed Christian argues that "the postcolonial detective $i s$ this space, this area of overlap, this space of meeting. In the detective the colonizer and the colonized collide, the oppressor and the resistor struggle for space" (2001, 11, original emphasis). For Persy, this struggle for space has two aspects. First, as a woman, she faces opposition from the masculinist police force. Secondly, as a Coloured person, she occupies a position in between Black and White, and thus finds herself at odds with both the old White elite and the new Black one. As a postcolonial detective, Persy is also

10 Historically, "[c]oloured identities were formed in the colonial encounter between colonists (Dutch and British), slaves from South and East India and from East Africa, and conquered indigenous peoples, the Khoi and San" (Erasmus 2001, 21). 
drawn into conflict with her own Coloured community. Applying Bhabha's concept of mimicry, Christine Matzke and Susanne Mühleisen view the postcolonial detective as "simultaneously a colonised subject and a postcolonial agent, a veritable 'contact zone'” (2006b, 11-12). Persy's conflicted status as a postcolonial detective, at once insider and outsider to the Coloured community, is exemplified by her relationship to Sean Dollery in What Hidden Lies. As her closest childhood friend, Sean not only shares Persy's racial background, but is privy to her childhood trauma - the fact that she was partly responsible for her brother's death in the kaolin mine. In What Hidden Lies, Persy expends a substantial amount of her detective energy hunting down Sean. Despite their common background, Persy managed to go to police college - thanks to Poppa's support - but Sean "succumbed to the thug life, like so many of their peers" (7). Persy's hatred of Sean transcends past loyalties, and she knows that their former intimacy will help her to get him behind bars (2013b, 6). Her feelings are reciprocated by Sean, who sees his own failure thrown into even sharper relief by Persy's relative success and resents the fact that she is frustrating his criminal activities. He calls her a "sell-out bitch [who] thought she was so high and mighty now that she was a detective, shaking the township dust off her feet, above him in some way" (10), and does everything he can to thwart her as a detective. He tries to ambush her (108-109) and sets fire to her caravan in an attempt to murder her (283-284). Persy narrowly escapes and immediately goes after Sean. She manages to shoot him, but he eludes her (286-287). Only by literally retracing their childhood steps up to the mine is she able to track him down. However, this means facing her long-suppressed trauma and guilt, which leaves her momentarily defenceless. Sean manages to overwhelm her and, at gunpoint, forces her to look out of the window of the house in which they hid from her brother twenty years previously. Once again, she witnesses her brother's death:

The giant metal claw rears up with its burden of dripping black earth. Persy can't move, can't think. The claw tips over. The black earth rains down and Clyde is gone.

Persy's knees buckled and gave way. She sagged heavily, and Sean's arm loosened on her neck. In that split second she brought his gun hand down on the jagged glass in the window with all her strength. He cried out. She heard the gun clatter to the floor. She pulled free.

$2013 \mathrm{~b}, 326$

The moment she faces the tragedy, including her own perpetrating agency, she also regains her detective agency. She can overpower Sean and thus pull free not only from the past, but from her captor. However, she no longer manages to 
cut herself off from him emotionally, and the fact that she has finally arrested him does not leave her feeling triumphant. The search that she carries out on Sean is not the jubilant action of a winner, but a fraught tracing of his body, a poignant gesture towards the loving intimacy that might have developed between them had their paths not diverged: ${ }^{11}$

"Turn around."

He turned around with his back to her, arms spread on either side of the window for support, his legs splayed. Keeping him covered, she searched him: her left hand moving up his thighs, patting the pockets of his jeans, around his buttocks and up under his jacket, feeling the crisscross ridges of the childhood scars on his bare skin. Beneath her hand she felt his ribs heave, as the wrenching sobs came without a sound.

$2013 b, 326$

From this point onwards, Persy is no longer able to view Sean as the abject criminal he has been for her so long. In front of the court building in which he is sentenced, she acknowledges their sameness: "She and Sean, the dispossessed. She had got away; he hadn't" (2013b, 346). She takes in the fact that, if she had not had Poppa to stand up for her, she could easily have ended up like Sean, even with Sean. When he is driven away to Pollsmoor Prison, for a last time "she recognised the boy she had known," resolves to visit him and lifts her hand in a final greeting (2013b, 346-347). This may seem sentimental, but as an authorial tactic the gesture is very deliberate: at the end of What Hidden Lies, the supposedly clear-cut divisions between detective, perpetrator and victim no longer hold. The ending of Hour of Darkness similarly dissolves the boundaries between Persy's roles as detective and as victim and exposes her indirect links to one of the perpetrators. Fred Splinters, the contract killer, finally manages to get the upper hand because his partner Natasha is probably Persy's long-vanished mother. This possibility gives Splinters a hold over Persy. On the pretext of enabling her to see her mother, he lures Persy into his trap. She escapes death only narrowly, and her mental breakdown as a result of her encounter with Natasha leaves her more victim than detective.

As an agent of the state, Persy has a substantial amount of legitimate agency as a detective, which allows her to solve her criminal cases and to unsettle gender norms. At the same time, as a Coloured, heterosexual woman, she sees her professional agency thwarted by the patriarchal frame to the point of

11 A romantic relationship between Sean and Persy was in the air for a while until Sean's dad was imprisoned and he moved away with his mother (2013b, 138-139). 
indefinite suspension from the police service. Having emulated the ideal of the masculine detective script and having striven for nearly two full novels to become a detective modelled on the masculine code of practice, as embodied by men such as her Black colleague Dizu and her Coloured and White superiors Titus and Tucker, Persy has become disillusioned. Her gradual and painful disaffection with regard to her male detective hero Tucker is indicative of this. Initially, she considers Tucker to be "by far the best detective she'd ever worked with. Disciplined, effective, driven, disdainful of the higher-ups, and full of a righteous rage he channelled into hunting criminals and, more importantly, convicting them" $(2015,70)$. Yet more and more she comes to disapprove of his decidedly masculine ways. She is bored by his "habit of always trying to out-dick the other" and by his pit bull strategy when interrogating suspects (108, see also 109-110). The final straw for her is the moment she realises that he is intimidated by their criminal blackmailers, when his moral integrity is at stake: "She could hardly believe it was Ren Tucker speaking. One of the most fearless, determined detectives on the force. Someone she had looked up to, admired and emulated" (279). By the end, she understands that aspiring to be like "old-school career cops" and following in "their hardass footsteps" (338) is not for her. She wonders "why she'd ever imagined that she and Tucker were soulmates. She was nothing like him" (339). The script of masculine, especially White masculine, detection and law enforcement proves to be inadequate: she definitely is "not that kind of cop."

\subsection{Persy Jonas: Female Detective Agency Reshaped}

Where does this leave the female detective's resistant agency? Is she ultimately powerless, her position ineffective from a feminist political viewpoint? I suggest that we look for Persy's resistant agency in different, unexpected places. Bonnie Honig offers a radically new take on the figures of Antigone and Ismene in Sophocles' tragedy Antigone. Whereas for centuries Antigone's martyrdom has been assumed to be for her dead brother, Honig opens up the possibility that it may have been just as much for her living sister Ismene. She shows how both sisters are faced with forced or impossible choices, but refuse to yield to such limitations by creating new possibilities. Insofar as these new possibilities are acts of conspiracy beyond the radar of hegemonic patriarchy and acts of sororal loyalty and solidarity, Honig views them as political as well as ethical $(2013,151-189)$. The notion that it is possible to counter the framework of forced choices favoured by patriarchy with creativity, and thus acting ethically and politically, can also be applied to the forced choices, or dilemmas, that Persy faces. Via Alenka Zupančič's elaboration of the Lacanian "forced choice," Honig explains that the classic forced choice "Your money or your life" is an 
impossible choice, because "the two terms are asymmetrical." Life is more than an oppositional alternative - it is the essential condition of the choice (172). If we compare this to the forced choices of Persy, our detective heroine - "Your heterosexual, Coloured, female life or your detective agency" - we can see that they are equally asymmetrical, equally impossible. Honig maintains that " $\mathrm{i}] \mathrm{t}$ is essential to an ethics of forced choice that the tested subject does more than simply yield to the force of the choice" (173). What is more, the passive resistance or civil disobedience of simply refusing to choose is not enough, since it is still a submission to the force of the choice. What is needed - and here Honig agrees with Zupančič - is a move "into the position of creator" (274), which entails generating a third possibility. Honig takes Zupančič further by specifying that this new possibility in Sophocles' tragedy 'refers to sororal solidarity" (173). This solidarity makes the act not only ethical but political. What is important for Honig is the creativity of the new possibility that allows the subject to resist the force of the choice, paired with the fact that this is done as a concerted action by partners (180). She calls this the "twinned negotiations of [two sisters'] forced choices" (182, my emphasis).

The cooperation (and non-cooperation) between Persy and Marge can be read as precisely such "twinned negotiations of their forced choices" (Honig 2013,182 ). This reading allows us to grasp the nature of the women's resistant agency. Persy and Marge negotiate their situational constraints as female investigators in a concerted, twinned action that requires both women to extend themselves and to make sacrifices. Persy and the White, elderly Marge meet over the dead body of the White Andrew Sherwood, which Marge finds during her morning walk on the beach. She is not only a key witness, but also a retired, renowned criminal psychologist, an advisor to the TRC and a former investigative partner of Persy's current boss Paul Titus. Persy is the first detective called to the crime scene. The two women feel an instant dislike for each other. At first, Marge mistakes Persy for a mere "sidekick", "an undersized coloured youth with short dreads and glasses," and is "momentarily taken aback by the effrontery of the boy, whose voice, by the sound of it, had not even broken" (Rowe 2013b, 26). Marge is soon made to realise that Detective Jonas is a woman, that she is in charge (or puts herself in charge) and that she does not welcome Marge's help. When Marge says that this looks like murder to her, Persy retorts, “'It's our job to decide that, ma'am' " (27), and asks a protesting Marge to move away from the crime scene. Marge deems Persy a patronising, "[o]fficious little cow!" (27). Persy, on the other hand, finds Marge's arrogance "breathtaking" (66) and experiences an allergic reaction to her cigarette smoke and the cat hair in Marge's home when she is subsequently sent to interview her (65). 
Despite their mutual aversion, Marge and Persy share a strong compulsion to work the Sherwood murder case. This is motivated partly by professional ambition: Persy needs a first murder case to further her career, whereas Marge needs new professional challenges now that both of her sons have left home. In addition to this, however, both women are drawn to the case by a semiconscious force that neither of them is quite able to articulate. Both women also encounter obstacles. To Persy's dismay, the case is initially assigned to her corrupt colleague Mhlabeni, with little chance of justice being done (59). Marge is an outsider to begin with, is retired and is forbidden to disclose confidential information about the patients whom she treats as a psychotherapist. And yet, thanks to coordinated action in Honig's sense, the two women manage to obtain and exert intersecting forms of agentive detective power in the Sherwood case. Marge gets the wheel turning when she realises that she needs a "proxy" in the police service in order to bring her wealth of background knowledge to the case. The only suitable proxy is Persy, so Marge asks Persy's superior to let her assist the detective (125-126). Knowing how much Persy wants the case, he offers to put her in charge on condition that she work alongside Marge. Persy grudgingly agrees to this "poisoned chalice" (147). In this way, both women achieve together what neither could achieve on her own. Still, the mutual resentment does not simply abate (152). The reader sees Marge's professional experience, arrogance and sense of racial entitlement pitted against Persy's competence, obstructionism and irritation at "being treated like a meid at the white madam's beck and call" (165). Their mutual distrust is heightened by the fact that each woman (rightly) suspects the other of having some hidden agenda, of hiding something. Only when Persy rescues Marge's beloved stolen dog Bongo from an illegal dog-fighting den does the tension between the two women begin to ease (187). A slightly humiliated Marge is aware that Bongo survived only thanks to Persy and shows gratitude: "There was an awkward silence. A shift had happened and neither knew what position to adopt" (208). This enables Persy to let Marge in on the fact that she was evicted from her home by her violent cousin. In return, Marge tells Persy about a friend who is looking for someone to caravan-sit. At first, Persy displays her "in-built aversion to any favours, especially one that came from Marge" (208), but eventually she gives in with relief at "having the older woman take charge" (209).

The picture that is being drawn here is one of a subtle, gradual alignment, through give and take. Each woman's moves are portrayed as mutually dependent on those of her colleague, the step of one triggering the step of the other. Their common point of reference in creating what Honig calls a new or third possibility is a desire for empowerment through detective work and an interest in solving the murder case. A further valuable benefit, as yet still 
undeveloped, will be the mutual support structure that reaches beyond detecting. At this point, however, not only is their solidarity reluctant, but they both have to concede the need to substantially extend themselves beyond their own received categories and experiences. What is required of them is to face and acknowledge past wrongdoings and guilt; we might as well call it a personal TRC move. Marge is plagued by guilt for mishandling Theo Kruger, the suspect in the Clyde Cupido case twenty years earlier, and thus driving him to suicide. She also finds it hard to accept that Clyde has never been found (236). Under increasing pressure from these "[r]eal-life ghosts crowding her, crying out for justice" (236), she comes to admit that she has a personal stake in the case and that "if she could find out what happened to Andrew Sherwood, she might feel in some way absolved" (236) - particularly as she senses a connection between the two cases (263-264). Again, Marge realises how dependent on Persy she is. "What would it take for them to overcome their mutual antipathy and neurotic projections? And if they weren't able to, how would they ever untangle the 'truth' of the Sherwood case, and bring the killer to justice?" she ponders (265).

For a positive change in their relationship to happen, however, Marge's past connection with Persy needs to be brought to light. This connection, of which neither of the women is conscious, reaches back far into the past. Twenty years ago, Marge, then a young criminal psychologist, and Persy's current boss Titus worked the investigation into the sudden disappearance of Persy's brother Clyde (28-29). When the two women interview Ivor Reitz, Marge's close friend and Andrew's landlord, Persy finds out that he is the White man who "bought" the land on which Persy's Poppa's smallholding was located (306-307). This convoluted happenstance both brings the connection between Persy and Marge to light and reveals that Ivor is partly responsible for the injustice done to Poppa, who was moved to a township and lost his source of income. Both women feel the effects of apartheid looming large over their relationship - "the racial divide yawned between them" (307). Marge begins to see Ivor - this admired friend, a man to whom she had also been attracted - in a more dubious light; In new-found humility, she eventually renounces her loyalty to him and sacrifices their friendship (343-344). In the plot development, it is now Persy's turn to admit her guilty role in her brother's disappearance, and thus facilitate the next turn of the screw that is her connection with Marge. Persy needs to sacrifice her innocence, too. After their visit to Ivor, she can no longer keep the floodgates to her long-suppressed trauma closed. She is finally able to articulate her own hidden agenda in the case. Realising that "[c]hasing down Sherwood's killer was like chasing down some lost part of herself, going deeper into that darkness" (313), she suddenly knows what she has to do: namely, to find her childhood friend and nemesis Sean up at the mountain, by the kaolin 
mine at Bellevue, in the house they were hiding in all those years back when they watched her brother being buried alive (315). Reliving that fateful moment, Persy sacrifices the blameless innocence she has long tried to preserve; to some extent, she sacrifices Sean, too, handing him over to the police. What she gains is a deep bond with Marge. She asks Marge to listen to her traumatic experience, certain now that "Marge would bear witness to her story without judgement or comment" (328). Marge agrees, and "Persy began slowly, haltingly, to speak, not sure if what she said made sense, or where the words were coming from, only knowing that she had to let them out before she shattered into a million pieces" (328). In this voicing, filling what had previously been the gap of silence and ignorance, the narrative ties the factual workings of empirical detection to the affective emotional-psychological knowledge of comingto-consciousness. For with Persy's account, Marge's own guilt becomes a fact. Theo Kruger, whom she suspected of being responsible for Clyde's disappearance, was innocent; she was indeed to blame for driving him to suicide. So the previously undisclosed secret personal agendas that have stood between Marge and Persy manifest as the bonds that have always tied them together, a deep entanglement through tragedy. Persy was right when she felt that she and Marge "were talking code. On the surface it appeared to be about Sherwood, but underneath it was about something else" (170-171).

Clearly, Persy and Marge make ethical choices. That they are political, too, as Honig claims they must be, becomes evident in the ways in which they defy the systemic obstacles to their detective agency. They negotiate the constrained choices of a racialised patriarchy and at the same time manage to engineer their own process of "truth and reconciliation" - beyond the immediate ambit of paternal law. This is clarified for us via Honig's contention that viewing heroic autonomy as the only form of political agency is limited, for it blinds us to "sororal and other solidaristic forms of agency and their powers" (2013, 155). Thus, while Persy's endeavour to claim the male space of the detective and his autonomous, heroic agency fails, her uneasy, troubled collaboration with Marge Rowe opens up another space for political agency: one that is resistant, but not simplistically so.

In a post-apartheid South African setting, the intricate entanglement of Persy's history with that of Marge in Rowe's novels can be read as a stand-in for interracial relationships on a national scale and as a model for future cohabitation and collaboration. And yet, from a racially critical viewpoint, reservations remain. Consider, for example, Marge's tendency to view Persy as a child. From one perspective, this is not problematic, as it can be attributed to their difference in age. However, given the racial hierarchies that inflect Marge's view, it can smack of the patronising, especially since the more their 
relationship develops, the more Marge sees the needy, vulnerable child in Persy (Rowe 2013b, 295, 301, 328). This persistent inequality in their relationship is at odds with the equality of their working relationship. As McClintock observes, infantilising the racially other long served as an alibi for imperial intervention $(1995,45)$. If the colony is fashioned "as a 'family of black children ruled over by a white father' " $(1993,64)$, the colonised is the immature child in need of paternal control. Subjugation is thus both naturalised and legitimised. When the White Marge views the Coloured Persy as a child, she is reactivating and reinforcing this controlling mechanism, a vestigial trace of power hierarchies that operated between coloniser and colonised. On the other hand, in the novel childhood is presented as a psychological protective mechanism, a form of "magical thinking" used in order to handle difficult situations, as Marge explains to Titus (Rowe 2013b, 329). Childhood is also a mitigating factor in judging Persy's culpability in her brother's death and in the fatal silence that characterises her afterwards. This makes the guilt that Marge, the adult, must shoulder all the more pronounced as she herself acknowledges: "Persy was a child. She wasn't responsible for what happened. I knew what I was doing" (329). Marge holds herself accountable, whereas she absolves Persy of guilt. Moreover, she fashions Persy not merely as a child, but increasingly as her daughter. Persy's rescue of her dog reminds Marge of the daughterly support that she has been denied because her own daughter was stillborn (209). The extent to which she allows Persy the position of a daughter and feels both protective and proud of her becomes evident when she asks herself whether her own daughter, who would now be exactly Persy's age, would be as " $[\mathrm{b}] \mathrm{rave}$, self-sufficient, vulnerable" (295) as Persy is.

Conversely, in Hour of Darkness, which depicts Persy grappling with the loss of her mother, Persy shows an increasing tendency to give Marge the maternal position. Thoughts of her mother often surface alongside thoughts of Marge, whom Persy describes as the person who was there when her whole world collapsed in the course of the Sherwood case. Persy longs to see and speak to Marge as a mother, yet is sometimes reluctant to do so because of their racial difference $(2015,39,196)$. It is Marge she confides in about her disastrous affair with Tucker (273), as well as Fred Splinters's attack and her mother's possible involvement, which left her so distressed (334). It is also Marge who looks after and comforts Persy after this incident, making it possible, finally for Persy to ask Marge about her mother, whom Marge met during the Clyde Cupido case. In a very motherly way, Marge protects Persy from the brutal truth that her mother displayed complete indifference towards her then seven-year-old daughter, telling Persy instead about their physical likeness, her hair and her eyes (334-335). At the end of the novel, Persy does not know for sure whether 
Splinters's partner is indeed her mother or whether she will ever see her again. Meeting the now motherless boys of Annette Petroussis for the last time, "Persy recognised her own lonely childhood. No one could take the place of a mother. Especially a good one. For some reason, Marge Labuschagne sprang into her mind" (342). With Marge allowing Persy to take her daughter's place and Persy allowing Marge to take her mother's, the bond between them becomes mutual and empowering on an emotional level, too. With Persy as an adult daughter and Marge as an aging mother, this is a move towards equality and solidarity where mutual need weighs up mutual benefit. It could pave the way for further, much needed female professional agency and collaboration in the third novel. Persy's move beyond the patriarchal frame of the police may give her and Marge the opportunity, when solving their next case, to continue exploring what Honig terms "a female agency that is agonistically and solidaristically sororal and not merely subject to male exchange" (2013, 170). By pairing Persy with Marge as an investigative partner and proxy mother, Rowe achieves a kind of genre bending. She modifies the conception of the detective figure as an autonomously heroic one - a conception not limited to the stereotypical male lone wolf, but found in female detectives, too. As Frizzoni notes, while many female investigators since the 199os operate in a social and professional network, they still adhere to an ideal of autonomous agency (2009, 104-105). By creating a mutually dependent investigative pair with effective solidaristic agency, Rowe changes the generic blueprint. Honig herself cautions that, in making sororal agency visible, she does not seek to normatively "promote sorority as a privileged site of agency" $(2013,183)$. What she foregrounds is "the politics of agonism, in which not only struggle and rivalry but also mutual respect and equality - even care - are characteristic elements" (183). This is exemplified in the contentious yet caring and empowering relationship between Persy and Marge.

\subsection{Truth-Finding:Persy Jonas's Detective Gaze and the Criminal Cases under Its Scrutiny}

A detective's truth-finding cannot be separated from the kind of gaze that he or she adopts. In her analysis of African American female detectives at the turn of the 1990s, Munt perceives a movement from "Black Woman as a sight, towards a new generation of investigatory visions, controlled by the shifting gaze of Black women themselves" (117-118). This insight can be applied to Persy. According to Ebert, the detective gaze is by default a Foucauldian panoptic instrument, "a means of power constituting reality and constraining subjectivities" in the service of the dominant patriarchal order $(1992,18)$. However, even though Persy is a detective and thus empowered, I would argue that her gaze 
differs fundamentally from the obliterating, sexualised and hence violent gaze on the female body discussed by Bronfen and Pollock, which aims to deflect from the threats posed by femininity, death and trauma.

Persy's first dead body is that of a White man, Andrew Sherwood. Her gaze on him bears no traces of patriarchal control, makes no attempt to classify, judge or fix him in place (Ebert 1992, 19). Persy's direct view of the dead body remains undisclosed to the reader, but we get her memories of it when he is being carried away in a body bag by the morgue attendants: "She kept seeing the corpse's pallid face in close-up." As she remembers the details of Sherwood's face, her own emotional response to and rapport with the victim are foregrounded. She records "her anger, and deep sense of grievance at the indignity of his death. What malice or passion or fear would cause someone to do this to another human being?" (Rowe 2013b, 37). Her gaze is anything but the objectifying, detached gaze of the detective. "Having never heard the timbre of his voice, his laugh, or seen him walk or eat or smile, she should be unmoved by his death" (37), Percy thinks to herself, but clearly she is not: she is shaken. Later, when she goes through the autopsy report and the photographs, her gaze is more objectifying and voyeuristic. She calls the photographs the "pornography of violent death" (147), but notices that she herself is partly depicted there, too. She also qualifies the pathologist's scientific, violent gaze by pointing to what he has in common with Andrew: drug abuse (151). In this way, she prevents easy distancing between male onlooker and male victim.

Persy's second case involves the dead body of a White woman, Annette. It is with great reluctance that she brings herself to look at Annette, "redirect[ing] her gaze" and "finding it hard to focus on the job" while the pathologist examines the body and Tucker searches the ground (Rowe 2015, 173). Having hoped against all the odds to find Annette alive, Persy again offers an emotional response to the discovery of Annette's body. Her gaze is empathic, intimate, even domesticated, despite the prosaic necessities demanded by her professional role at the crime scene: "Persy pulled on some gloves and forced herself to kneel beside the dead woman. Thank God Kai and Alexi would never see their mother like this. The image of the smiling woman in the photograph on their refrigerator door would be what they would remember" (173-174). Only now does Persy do what is required of her. She takes detailed notes on Annette's clothes and the drag marks on her skin, while picturing her last moments and thoughts. This leaves her shaky and aching: "[s]he had to put Kai and Alexi out of her mind or she would be no use to this investigation" [174]. Again, Persy is aware of the difference between an objectifying and a compassionate gaze. The latter is more difficult to handle emotionally, but it allows her to be touched, to see the victim's trauma and the traumatic ramifications of her 
death for her young family. Persy's empathic gaze prevents her from sacrificing the victim and deflecting from her trauma, from exerting power. Through Persy, Rowe successfully shifts the site of interrogation away from the dominant White phallic position to the female detective of colour, who is able to see women, not woman. It is this empathic gaze, coupled with her different subject position, that also allows her to bring specific crimes to light.

The crime that sends Persy on her first truth-finding mission is the murder of Andrew in What Hidden Lies. Quite unexpectedly, his murderer turns out to be his ex-partner, a White woman called Colette McKillian. The parameters of this crime remain firmly grounded in the individual characters and their relationships. Colette kills Andrew in what she believes is self-defence during an argument fuelled by a fatal mix of alcohol, medication, Colette's long-standing suspicion that Andrew has sexually molested her son Jasper and Andrew's equally long-standing view that Colette is an unfit parent due to her mental illness (340). In a way, they are both victims of Jasper's real abuser, Gregory Crane, who also is White, and who spreads rumours about Andrew and manipulates Colette in order to deflect attention from himself. The novel does not explore possible structural reasons behind child abuse - it is only hinted at that Crane grew up in a care home and was himself a victim of sexual molestation (290) - mental illness or single parenthood. However, the Sherwood case leads Persy and Marge to the "truth" about the cold Clyde Cupido case and their reciprocal personal involvement. Their individual journeys of trauma and recovery have significant ethical and political reverberations, as I have already discussed, but the apartheid structures that rendered Persy vulnerable as a child in the first place, that failed to protect her, are not investigated further. This is despite the fact that we learn that it was more than curiosity that regularly drove Persy and her friend Sean out of their homes to the forest near the kaolin mines. The forest was a place of refuge, sheltering Sean from his father's violence and Persy from her mother's indifference (2013b, 29, $264,277,297,2015,334)$. However, the interplay between the constraints of the apartheid system, and the debilitating family structures that it produced, and Persy's mother's choice to be a single parent and to seek solace in alcohol is not part of the novel's truth-finding process. Here Rowe's narrative repeats the TRC's shortcomings by depicting trauma as event based and by failing to shed light on the interaction between the system and individual actors. For Posel, this complex and elusive dynamic must be considered if truth-finding processes are to be meaningful, but the TRC did not sufficiently establish the links between individual agency and broader structures $(2002,168)$, preferring to highlight epiphanic or cathartic moments of individuated, often spectacular, confession, confrontation and appeal. 
In Rowe's other novel, by contrast, Persy's investigation into the murder of Annette Petroussis brings to light a more complex "truth" that links systemic crimes with individuals' lives. Like Andrew's, Annette's murderer is a woman. The seventeen-year-old Xhosa teenager Mandisa Dasheka kills the affluent White Annette in a robbery gone wrong and rescues Annette's baby (287-289, 291-293). It is made clear that the criminal here is not Mandisa alone. Equal blame is put on criminal socioeconomic and political systems such as Mandisa's precarious living conditions, an apartheid legacy that makes her vulnerable to post-apartheid criminal Ricardo Heinrich in a gender-specific way. Mandisa's mother has worked as a domestic servant for the wealthy, White HamiltonLangford household for a long time, a fact that leaves Mandisa humiliated, jealous and full of hatred. Not only does she detest that "[e]verything [her] family owned was 'rubbish' the Hamiltons had thrown out" - "the hand-medown clothing" particularly disgusts and humiliates her (232) - but she feels deprived of a mother, fearing that the Hamiltons mean more to her mother than her own family: "She especially hated Severine. [...] It was as if her mother had a white daughter in the suburbs, a white daughter whom she looked after and took care of in a way she never had for Mandisa" (232). Her mother's work-related absence also means that the housework and care of her siblings are left to Mandisa: "Sometimes she felt like the family slave" (232). It is easy to see how this drives her into the arms of a boyfriend. Axolile Sama lures her with his attention and material possessions: his car and expensive gifts. Thus, when he asks her for her mother's keys to the Hamilton-Langfords' house, suggesting that she accompany him on a robbery "to teach [grandfather Langford] a lesson" (287) - a robbery commissioned by Heinrich - she readily consents, unable to imagine the consequences. The consequences of Mandisa's actions are fatal for Annette, whose house they mistakenly break into, for Axolile, who is killed by the kingpin, and for the future of Mandisa and her family.

This layered attribution of the "truth" behind Annette's murder deftly eschews more typical crime patterns of spectacular revelation and is successful in several respects. First, through Mandisa we are given the perspective of the young, Black, normally invisible daughter who has to share her mother with a White family. Although this situation is extremely common in South Africa, the divided attention of mothers of colour is hardly seen as an issue; it is still more unusual for the perspective of their own daughters to be highlighted. Turning unthinkingly to a clichéd trope of South African life, Severine naturally introduces her family's domestic servant as "my second mom" (282). She does so in Mandisa's presence, blithely unaware of the implications for Mandisa. Severine's friend Jos does notice and observes, "Severine hadn't seen, but if looks could kill, the glare Mandisa gave her would have" (282). What is more, 
it is not only employment as such that keeps Mandisa's mother away from her own daughter. The fact that her journey to work takes several hours - another direct effect of the segregated geography imposed by apartheid - aggravates the situation (98). Here, Rowe interrogates dominant perceptions of interracial relations and draws attention to blind spots. Such complex truths have the potential to create the basis for a new kind of understanding. Her truthfinding process moves beyond the "who done it" and sheds light on the reasons behind the crime. She does so in a way that Posel deems crucial in processes of truth-finding: she tries to understand " $w h y$ individuals act the way they do by inserting their actions into a broader causal context" (2002, 159). Mandisa is undoubtedly rendered as an agent, too. While she is constrained by larger structures, she also takes decisions that shape and even extinguish others' lives. Individual guilt is not glossed over. Reflecting on the fateful night, she keeps asking herself "why she hadn't told the white woman to drive away while [her gangster-boyfriend] Axe was in the tavern" (291). Posel and Simpson emphasise the importance in the truth-telling process of moving beyond "simple moral binaries of 'victim' and 'perpetrator' associated with unambiguous judgements of right and wrong" $(2002,10)$. Mandisa exemplifies this complexity.

Secondly, the novel draws attention to how race interacts with other categories such as gender and class. Mandisa's brother suffers less, for example, because as a boy he is not expected to do housework (Rowe 2015, 232). For the individual criminal masterminds, money has superseded race as a motive, as Persy points out (88). Democratically elected politicians of colour such as Heinrich use their political and material power to collaborate with privileged Whites such as Gray Langford and become complicit in the exploitation of those marginalised by gender and skin colour. And even though their criminal machinations are exposed, they experience no repercussions. A political system that is characterised by widespread corruption exonerates individuals, especially if they hold positions of social influence.

Thirdly, both the Sherwood and the Petroussis murder cases expose the issue of land ownership in South Africa and the ways in which past structural inequalities in ownership based on race both persist and have become more complex in the post-apartheid present. ${ }^{12}$ Both novels highlight land issues in their historical dimensions. In What Hidden Lies, this happens through Persy's family history. Up until the late 1980s, Persy's grandfather had a lease on a smallholding on the

12 In What Hidden Lies, land issues indirectly facilitate the novel's murder case. Sherwood is an obstacle to Crane's plans to develop Bellevue, so Crane spreads rumours about him that feed Colette's suspicions and thus indirectly contribute to his murder. In Hour of Darkness, Annette's murder is a direct result of land issues. 
coast in Noordhoek. When the White owner of the big house nearby wanted more land, he pressed Poppa for the title deeds. Poppa could not produce them and was forced to sell his smallholding for a pittance. There was nothing that Poppa could do since, according to the Group Areas Act, "coloureds were not meant to be living in this area anyway. It had been zoned for whites long ago" (313). With the law against them, Persy's family was moved inland to the township of Ocean View, which was designated for Coloureds (11, 89, 306-307). The history of Poppa's smallholding in Noordhoek mirrors that of the Coloured flower farmer Moses Petersen and his Summerley farm in affluent Constantia, which features in Hour of Darkness. These are "[p]atterns repeating in Cape Town's history" $(2015,79)$, as Persy points out. We hear that Constantia was first claimed by the governor of the Dutch East India Company, Simon van der Stel, in the 17th century as part of his Groot Constantia farm. He brought "slaves from Java, Madagascar, Mauritius, Zanzibar" (201) with him. When they were eventually freed, they were sometimes given subdivisions of the farm as owners or tenants. However, when the area was declared "Whites only" by apartheid law in the mid2oth century, White people bought the land cheaply from the Coloured community, which was evicted to the townships on the Cape Flats (133-134, 201-202). Through Persy's murder investigation, Hour of Darkness, which in parts reads like a history book, remembers and attests to the historical intricacies of land use, ownership and tenancy. Land restitution is a sore point for South Africa's historically dispossessed, as Persy tries to make clear to Tucker when they argue:

"And where will it all end? Must we sommer now give the land back to the bloody Bushmen, or Hottentots or whoever?" Tucker was off, riding a favourite hobby horse. "The blacks would have to fuck off back north and the whiteys can trek back to Europe and we can all go back to the fucking Stone Age."

"En die bruinmense? Where are we supposed to go?" [Persy] asked with a bite in her voice. He shook his head. "Now you are insulting my intelligence."

"Don't we have legitimate claim to the land you stole from our forefathers?"

188

Tucker's insults and Persy's insistence on the complicated position of the "bruinmense" (the "brown" i.e. Coloured people) are illustrative of the various conflicting discourses that arise from the many ethnic groups that have laid claim to the land over time. This complicates any "simple" notions of "racism" as an explanation (Posel 2002, 168). Both novels also depict how, in contemporary South Africa, land issues have begun to cut not just along but across racial lines, through expedient alliances between wealthy White property owners 
and corrupt politicians of colour. Analysing aspects of South Africa's present economic situation and its underpinnings of race, class and gender, Achille Mbembe notes that the end of apartheid has accelerated the country's transition from a "society of control to a society of consumption," thereby aggravating old structural contradictions tied to property ownership. "At least since the wars of dispossession of the 19th century, citizenship and rights of personhood have been constructed in relation to a particular regime of ownership. Whites owned property and blacks sold their labour at a cheap price on a captive market" (2014, par. 9). In the present, Mbembe claims, "processes of accumulation are happening, once again, through dispossession - except that this time round dispossession is conducted by an increasingly predatory black ruling class in alliance with private capital ${ }^{13}$ and in the name of custom and tradition" (par. 13), the latter being fashioned in explicitly patriarchal terms (par. 26). While neither novel explores the gender dimensions of land issues, both of them expose the crimes of this new alliance and show who suffers as a result: namely, the expropriated owners, the landless and the natural world of plants and animals. Marge is quick to identify the mechanisms of "self-enrichment posing as social conscience" in both politicians and property owners (Rowe 2013b, 77). Commenting on the impending Bellevue property deal, she foresees that " ' $\mathrm{g}]$ ]overnment cronies will get their kickbacks while passing it off as a localhousing initiative; the developers will make a killing, and the rich buyers will feel safe in their electrified shoeboxes. It's a win-win situation' " (77). In Hour of Darkness, Persy's investigation reveals the same dynamic at work. The Coloured politician Heinrich pretends to represent the interests of the original inhabitants of Constantia, when in fact he is instrumentalising them in order to fill his own pockets $(2015,148-150,131)$. Here again, the interaction between the system and its actors is revealed. However, despite exposure, many of these systems stay in place and many criminal individuals go free, rendering justice incomplete.

\subsection{Criminal Justice and Alternatives}

In the last section of this chapter, I will discuss Rowe's novels as reflections on state-administered, formal criminal justice, examining the ways in which the female detective and her investigations not only serve the criminal justice system, but resonate with the more inclusive, restorative notions of justice put forward by feminist legal scholars. Persy has her doubts as to the kind of justice

13 According to Mbembe, "[t]o a large extent, South African capitalism still depends on the institution of migrant labour, a highly unequal and racialised partition of land and a thoroughly extractive economy" (2014, par. 18). 
that is achieved by her arrests of Sean and Mandisa. Even though she is instrumental in arresting Sean at the end of the first novel, increasingly she comes to regard his imprisonment as an inadequate solution. If anything, she feels that his time in prison is likely to criminalise him further (Rowe 2013b, 347). Mandisa's arrest leaves Persy even more frustrated. She feels deflated when Annette's killer turns out to be Mandisa, who got caught up in murder almost inadvertently. "I so wanted to find Annette's killer. Now I just feel sick," she remarks $(2015,297)$. In the end, the kingpins behind Mandisa's crime, the likes of Langford and Heinrich, walk free.

Persy's physical discomfort at discovering Mandisa's guilt against the background of larger injustices is symptomatic of a tension typically experienced by female detectives in feminist detective novels. According to Walton and Jones, the individual crime is solved and individual criminals have been identified, but the criminal systems persist (1999, 208-213). They observe:

at the same time as the narrative forecloses on the enigmatic aspect of individual crimes in a traditional way, it is also structured according to the disclosure of less easily resolved endemic injustices and oppressions, making possible a level of social or psychological inconclusiveness and thus critique.

211

It is in displaying a "consciousness about such conflicts" that the crime narrative's political thrust lies, in the "unsettling disruption of established norms" (212). With Persy, Rowe goes a step further. As Persy comes to recognise the inherent violence in the work of the police ("Could a detective be an instrument of peace? Cops were required to maintain some kind of harmony in society. With brute force if necessary" (Rowe 2015, 267) $)^{14}$ and has to acknowledge that she is "not that kind of cop," her reservations increasingly point to the concept and system of justice itself. The discrepancy between the crimes exposed by Persy and what happens in practice in the criminal justice system, where the true culprits are not held accountable, renders the system and its ineffectual legal foundation criminal. Feminist legal scholars and feminist criminologists have long challenged the seeming neutrality of the law and the criminal justice process. They have established that "law in western societies reflects the subjectivity of the dominant, white, affluent, adult male" (Hudson

14 See also Walter Benjamin, who in his "Critique of Violence" elucidates the violence inherent in the law and in the institution of the police. He sees the role of the police as ignominious, since "in this authority the separation of lawmaking and law-preserving violence is suspended" (62). 
$2012,385)$. This liberal notion of subjectivity as governed by reason privileges behaviour denoted as male (Büchler and Cottier 2012, 252-253). Karin van Marle and Elsje Bonthuys criticise the fact that "[p]atriarchal interpretations of justice and equality exclude qualities like emotion, relationships and care, which characterise the lives of women, while valorising abstraction and independence, which are associated with male behaviour in the public sphere" $(2007,21)$. As a result, social situatedness and social relations are removed from legal perception (Büchler and Cottier 2012, 254), and the law's ability to perceive and respond to the problems of those who fall outside its narrow frame, such as women, is impaired (Van Marle and Bonthuys 2007, 29). Thus, the law both protects and produces White, hegemonic, male subjectivity and behaviour: "The law not only accepts male life experiences as the basis for the formulation of universally applicable rules, but the very structure of legal reasoning replicates the ways in which men of particular racial, class and social status are socialised to think and behave" (45).

In order to "move beyond the closures and exclusions of white man's justice" (2012, 384, original emphasis), Barbara Hudson suggests an alternative, more inclusive notion of justice that is based on the three principles of discursiveness, relationalism and reflectiveness $(2012,388)$. Her principles are closely related to, though not identical with, what is termed "restorative justice" in legal discourse, the tenets of which underlie the "transitional justice" that the TRC was seeking to achieve. "Restorative justice" denotes a form of justice that is victim based and espouses values such as "truth, accountability, reparation, reconciliation, conflict resolution and democratic participation" (Doak and O'Mahony 2012, 305). Facilitating meaningful dialogue and "restoring relationships to community as well as between victim and offender" are central to restorative justice (Hudson 2012, 394). Restorative justice is generally perceived as opposed to conventional criminal justice, the kind of formal justice dispensed by the state, which focuses on the perpetrator by ascertaining his/ her guilt and delivering punishment. The three principles of discursiveness, relationalism and reflectiveness suggested by Hudson are realised to a higher degree in restorative justice than in established criminal justice. At the same time, Hudson criticises restorative justice for its tendency to revert to "the closures of male, white justice" (395) when confronted by practical and ethical dilemmas. It is these closures that her three principles seek to transcend. First, they give "free rein" (395) to a proposition of discursiveness, which demands that everyone has equally privileged access to discourse (389). Those "outside the discursive circle of justice must be brought inside" and "the outsider must be able to put her claims in her own terms, not have to accommodate to the dominant modes of legal/political discourse" (389). This includes ensuring 
that there is space for any topic; in particular, "behaviour in the private sphere must not be off-limits" (390). By investigating crimes from the perspective of a young woman of colour, Rowe allows such outside positions to become heard and visible, as I have already shown. Private issues such as the pain and jealousy of a Black teenage daughter who must share her domestic worker mother with a White girl who by implication styles herself a "sister" can be disclosed. Secondly, Hudson argues that inclusive notions of justice must adhere to the principle of relationality. Relationality, as she understands it, "recognizes individuals as embodied in a network of relationships, which include relationships with community and with the state" (392). Crucially, Hudson views not only identities and rights but responsibility and culpability as relational (392). Rowe takes the principle of relationality in account both by valuing the collaborative cooperation of Persy and Marge over male, liberal conceptions of individual, heroic agency and by highlighting the role of systemic violence and the way in which it interrelates with individual culpability. Finally, reflective justice requires reconceptualisation of the very (male, White, bourgeois etc.) legal categories that delimit what is relevant or irrelevant in legal judgement, what is admissible and what is not (393). Reflective justice works against a "restricted range of legal categories of crimes, aggravations and mitigations which [...] abstract individuals from wider inequalities and oppressions" (394). Instead, it aims at "situating particular circumstances in their wider social context" (394). This principle is clearly operative in Rowe's fiction. Whenever Persy draws attention to the frame of structural inequality, by implication she prises open the constricting determinism that underpins the received legal categories of crimes. Moreover, Rowe calls into question the "abstract generality of the law" (Hudson 2012, 393) - and the rationality that underlies traditional detection, too - by including and valuing supernatural powers in her crime novels. In What Hidden Lies, justice is dealt out to one of the culprits (Gregory Crane) by supernatural circumstances outside the criminal justice system. They lead him to what the latter would frame as a suicide (318). In the second novel, Severine's visitations by the Virgin Mary help to save her and many others when she gets caught up in a pharmacy robbery (312). Even though later her "religious hallucinations" are scientifically explained by her mother as the effects of a benign brain tumour, a mere "brain malfunction due to neurobiological reasons" (336), Marge feels "a whisper of a doubt" stir in her and considers the possibility that there may have been more to Severine's visions (336). The novels hint at such alternative realms of power on those occasions when Persy's life is saved by animals - for example, when a cat alerts her to the existence of a cat flap and thus provides her with an escape route from the burning caravan (2013b, 284), or when she escapes Splinters' attack thanks to the sudden materialisation of 
Houdini the hippo, which causes her attacker to flee $(2015,330)$. In such instances, the achievement of justice cannot be objectively measured. The episodes have a quirky, playful and serendipitous quality, which, while provoking scepticism in some readers, can be read as a deliberate attempt by the author to trouble the foundations of more rationalist legal solutions that all too often fail to effect change, to extend empathy or to credit underlying causes. While these episodes do not destroy the novels' rational underpinnings - Rowe does not, after all, write magical realism - they hint at the limitations of justice as conventionally conceived, teasing open the realm of imaginative possibility so that other, as-yet-unforeseen and perhaps more culturally inclusive forms of justice can be considered.

In the first two novels of the Persy Jonas trilogy, Rowe successfully unsettles both crime genre conventions and the gendered and raced social and legal norms that form the basis for the South African post-transitional real. Her in many ways unconventional detective heroine Persy has her detective agency triply compromised on the grounds of her gender, sexuality and race, yet she counters the constrained choices into which the various constricting frames would coerce her. Rather than bartering her female, heterosexual subjectivity of colour for her agency as a detective, Rowe creates a third space of agentive intervention for her heroine through concerted, if agonistic, collaboration with Marge. Together, they trouble the patriarchal criminal justice system and resist its exclusionary mechanisms at the same time as they are compromised by it. While the occasional sexist or racist controlling mechanism is at work in Rowe's representation of her detective protagonist, Persy nevertheless constitutes an exploratory revisioning of the gendered and raced script of autonomous, heroic detective agency. Persy's multifaceted outsider-within position allows her to ascertain complex truths about land rights and White employment of female domestic servants of colour in South Africa that not only move far beyond a simple "who done it", but highlight the ways in which power, responsibility and culpability oscillate between systems (patriarchy, colonialism, apartheid, capitalism) and individuals. She thereby continues to establish the kinds of truths that the TRC was mandated to uncover. Recognising the relationality between systems and individuals is in itself a means of serving justice so as to counter the bias inherent in the formal criminal justice system. Allowing access to non-dominant positions and voices that speak in non-dominant ways about otherwise hidden (e.g. domestic) issues, thereby bringing them into the realm of the political, further works towards establishing more inclusive notions of justice, while resisting and negotiating the formal justice system's deceptively liberal constructions of race and gender. 


\title{
Not What South Africans Expect: Hawa Jande Golakai's Investigator Vee Johnson
}

\author{
"You're not what I expected." [...]. "How come your name's \\ Johnson?" [...]. \\ "In a nutshell, I'm related to the president of my country. We're all \\ royalty, so we get to rule.” [...]. “Oh, you're messing with me. 'Course \\ you're not related to a president" [...]. "That's what I mean by you're \\ not what I expected." \\ MARIEKE and VEE in The Lazarus Effect (169)
}

Hawa Jande Golakai's heroine Vee Johnson hardly conforms to South African's expectations of immigrants from other African countries as she roams the streets of Cape Town. She confounds expectations in multiple respects. Vee (Voinjama) is a stylishly dressed, female investigative journalist who works with Chloë Bishop, her White, lesbian sidekick. The almost 6-foot-tall Vee is a Liberian refugee and holds a "top-class degree in journalism and media from Columbia University" (Golakai 2011, 39). She is generally hard to place for South Africans, both racially and linguistically. Given her black skin, in the Western Cape Black people react with incredulity when they realise that she does not speak Xhosa $(2015,47)$. Her surname evokes puzzlement, as she is "obviously not coloured" $(2011,46)$, and people struggle to pronounce her first name: “'Miss Va ...um, Viona ... Voiaja ... uh, Miss Johnson'” (2011, 25). Her English accent gets noted as "very different" (45) or, less diplomatically, as sounding "like a Jamaican reading a dictionary" $(2015,67)$. In short, Vee resists easy accommodation within South Africa's racial and linguistic grid, and this is where her power for renegotiation of generic and social scripts lies. With Rowe's protagonist Persy, Vee joins the ranks of the feisty, tough, hard-boiled investigator heroines of the crime genre as a woman of colour. While the two are subjected to similar tensions and dilemmas as female agents in a maledominated professional environment, with Vee, Golakai adds several decidedly new twists to the female investigator in local crime fiction: an outsider's view on South African society, an unprecedented combination in a female detective duo and the opening up of the crime genre to include elements of chick lit.

My discussion of Golakai's budding Vee Johnson Mystery series follows three main avenues. The first is concerned with the revisionary potential of Vee's agency as an outsider detective and her collaboration with Chloë. Vee and Chloë as a detective duo represent an impressive revision of racial relations that can hardly be overestimated in the South African imaginary. The second part of the chapter critically engages with Golakai's genre blending. 
I argue that her infusion of crime fiction with chick lit gives rise to certain tensions, but that, overall, it is a successful feminist intervention. Finally, I look at the kind of truths that Vee is able to establish in her investigative work and the fictional justice that she thereby serves. Here my arguments are again underpinned by the feminist scholarship in legal studies and criminology cited in my discussion of Persy Jonas. I suggest that Vee's endeavours in this area display contradictory effects, simultaneously opening up and closing down opportunities for more inclusive modes of justice.

Hawa Jande Golakai's debut detective novel The Lazarus Effect (2011) was an instant hit, receiving nominations for three prestigious literary prizes. The novel was long-listed for the Wole Soyinka Prize for Literature in Africa and short-listed for the Sunday Times Fiction Prize, as well as for the University of Johannesburg Debut Prize for Creative Writing (Steiner 2017, 1). The Score (2015) is the second novel in Golakai's Vee Johnson Mystery series. A trained immunologist and a newcomer to the crime writing scene, Golakai says, "I want to reclaim crime writing as an African woman" (McCracken 2014, par. 19). In her biographical note in The Score, she calls herself "a modern-day nomad and cultural sponge." Born in Frankfurt, Germany, she spent her childhood in her family's country of origin, Liberia, but in 1990 was compelled to leave due to the Liberian Civil War. After moving around several African countries, she came to South Africa in 2003, where she lived for almost a decade before returning to Liberia (Akinwotu 2016, par. 6, 17).

The Lazarus Effect is set in Cape Town in 2009 and features investigative journalist Vee Johnson's first case, the disappearance of the teenage girl Jacqueline (Jacqui) Paulsen, who had gone missing two years earlier. While Vee is unable to raise Jacqui from the dead (as implied by the title), she certainly saves her from oblivion by reviving a cold case. Troubling hallucinations featuring the teenager kindle Vee's interest. She manages to establish not only the "truth" about the emotionally crippling life of Jacqui's family, but that Jacqui was murdered by her half-sister Rosie. In The Score, Golakai's second detective novel, "the score" has nothing to do with football, but refers to settling an old score in the business world in post-World Cup 2010 South Africa. Vee's investigation into the murders of Gavin Berman and Rhonda Greenwood in a lodge in Oudtshoorn, in South Africa's Western Cape province, reveals the exploitative business practices that motivated the murderer, IT specialist Xoliswa Gaba.

The Politics of Vee Johnson's Detective Agency and Her Collaboration with Chloë Bishop

Vee is not on an explicit mission for feminist and racial equality, but her visibility as a successful female migrant investigator with detective agency and 
the confidence and naturalness with which she claims and manages to secure her own space as a Liberian woman within the male-dominated media work towards these ends. Vee's very choice to become an investigator is informed by political concerns. The investigative journalist attracts crime like a magnet (Golakai 2015, 79) and her motivation to fight it is strongly personal, yet in Vee's case the personal is also political. Shedding light on Jacqui's mysterious disappearance in The Lazarus Effect is an act of self-preservation for Vee, as is finding Gavin's murderer in The Score. Vee suffers from panic attacks and repeatedly experiences disconcerting visions of a teenage girl in a red woollen hat. Rightly suspecting that this "ghost" that keeps bothering her is Jacqui's, Vee knows that "her own health and sanity depended more than her livelihood on finding the 'truth' behind Jacqueline Paulsen's disappearance" $(2011,47)$. Living at the intersection of at least two cultural spheres, Vee has various interpretative models available to account for her "anxiety attacks" and concomitant "hallucinations". According to a Western scientific belief system, she is suffering from posttraumatic stress disorder (157), whereas from an African traditional viewpoint she is being visited by a spirit (150). Neither system is a feasible choice for Vee, however, as both are undergirded - more or less overtly - by patriarchy. She feels uncomfortable about seeing a psychotherapist, and the Nigerian spirit consultant she once saw turned out to be a violent lecher $(37,150)$. By rejecting these alternatives, Vee implicitly refuses to allow herself to be pathologised and thus controlled by patriarchal structures. Instead, she herself takes the traditionally male space - that of the detective - thereby opting for an actively resistant strategy. In the second novel, Vee's personal motives for investigating Gavin's killing are likewise political: her detective work is a refusal to be criminalised. Shortly before Gavin is found murdered, she has to fight off his sexual advances. In the course of this struggle, she loses her scarf and leaves the marks of her fingers around his neck $(2015,72)$. She does not kill him, but the evidence of her scarf and the strangulation marks around his neck lead the police immediately to regard her as a prime suspect. Vee knows that, given her vulnerable foreigner status - a "kwerekwere with [an] unpronounceable name" (88) - she is liable to be criminalised by a xenophobic South African society. Xoliswa drives this point home when she tries to blackmail Vee later on, detailing how Vee's version of events would not be believed by the police (289) precisely because of her foreignness. Vee's gender and race are also factors in her decision to investigate Gavin's murder. By choosing to exert her agency as a detective in The Score, Vee is resisting the stereotype of the criminal Black woman, a controlling mechanism that dates back to colonialism. Lewis maintains that "colonial definitions of [black] women's urban work as peripheral and unlawful, together with the stereotypes surrounding their presence in towns, frequently persist in 
the post-colonial period" (2011, 206). Occupying the position of the investigator and exercising detective agency as a Black immigrant woman in South Africa gives Vee a legal status in the public sphere, a kind of visible social authority on the street that is on the right side of the law. Her choice to investigate becomes an act of inventive recasting of received social categories.

The question remains as to whether this choice actually allows Vee extended scope of action. Vee's agency as a detective repeats the male blueprint; it is that of the lone, heroic, tough, authority-defying male noir hero (2011, 241, 247, 274-276, 2015, 233ff., 257-258). Vee loves and frequently embarks on "solo missions" (2011, 38), and, with her excellent combat skills, she is generally happy to engage in physical fights. Her heroism is rewarded in the media world: both Rosie's and Xoliswa's attacks and the way in which Vee resists them enhance her credibility with her superiors and substantially boost her career as an investigative journalist $(2011,237,2015,184)$. Unlike Persy, Vee is rewarded for her performance of the male detective model. It works to secure her the visibility and the place in the male-dominated media world that she covets.

In addition to her gender and race, Vee's migrant status has an important bearing on the political implications of her agency as a detective. In her discussion of The Lazarus Effect, Rebecca Fasselt emphasises the significance of the migrant detective in a South African context, where more often than not immigrants from other African countries are perceived as a threat to local livelihoods and are frequently subjected to violent assault and murder (2016, 1111-1112). Reading Golakai's first novel alongside other South African crime novels that address similar concerns, Fasselt points to the uniqueness of Golakai's perspective (1113). She views The Lazarus Effect as "a powerful vehicle for an enquiry into constructions of 'foreignness' and a means to allot a space to African migrants in the 'new' South African imaginary" (1109). Not only does Vee move beyond the space of stereotypical female migrant victimhood, as Fasselt argues (1122), but, as a female investigator, she fights to secure a space within the male-dominated institutional framework of the media. Vee's career trajectory as an investigative journalist takes her from Cape Town's Urban magazine, which is presented by Golakai as having strong female connotations, to inhabiting her very own office space in the "male" Chronicle. Vee starts off at the Urban, which "makes most of its revenue from fashion. [...] by appealing to urban women with a fashion sense" (Golakai 2011, 82). Here Golakai is somewhat simplistically reinforcing existing assumptions about female fashion media as limited, so it comes as no surprise to the reader that the power of Vee's female boss, the editor Portia Kruger, is constrained. Rumour has it that she is "no more than a seat-warmer" put in place by her father (39), who owns the media group made up of the Urban and the more prestigious City Chronicle 
(41). The Chronicle, headed by the White managing editor Nico van Wyk, is the larger and "more respectable newspaper," where the "serious material" is published and where the decisions are made (41). Following Vee's success in the Jacqui Paulsen case, this is where we find Vee and Chloë at the beginning of The Score. However, her posting to the Chronicle is an uncomfortable space for Vee. She is reined in by Nico, "a racist dick" $(2015,20)$ whose office is described as "a man's space" (14). She finds herself jammed into "a cubicle next to a sealed-off window" (14) and being sent on a fatuous travel and tourism assignment to the Grotto Lodge in Oudtshoorn (19). Once there, Vee decides to do the forbidden and steps outside the confines of her narrow job description to investigate two murders at the lodge. Her transgressions are met with opposition for a long time, but eventually she wins Nico over with her investigative success and the financial gains that accrue to his paper as a result. Somewhat defying Vee's simple labelling of him as misogynist and racist, he rewards her with a promotion to the online team (348). While she still has a way to go to reach the coveted crime desk, which for now remains occupied by two men who swing "their dicks around" and "muscle out" women (134), she has made inroads into the management sector of the male-dominated Chronicle (359). What is more, inside this structure, she has secured her own office space, a room of her own, her "place to think" (17), her refuge from the noisy, "old guard" newsroom where her personal space was constantly interfered with (17). This office stands for her own gendered and cultured space in which she, the African female migrant detective, further negotiates the terms and conditions of her job with her White South African boss Nico (351-352).

Finally, there is political significance in the professional pairing of Vee and Chloë, who is both White and lesbian. This strategic authorial pairing implies a provocative contestation of various established power relations in South Africa and jars with the traditional feminist notion of "sisterhood (in crime)". The dynamics of Vee's relationship with Chloë are characterised by clear hierarchies. Vee is in the superior position to Chloë, which constitutes a radical reversal of power hierarchies that generally place the Black migrant woman beneath the White South African woman. Vee's seniority is established from the beginning through the power of the gaze. When she sees Chloë for the first time in The Lazarus Effect, Vee looks at her through the blinds between two offices without Chloë's knowledge and without Chloë being able to look back (81). In a detective novel, such a scene is immediately evocative of the one-way mirrors in police interrogation rooms. Through Vee's one-way gaze, Chloë becomes the suspicious object of investigative enquiry; she is being scrutinised and exposed without knowing the source, number and nature of those who have her under surveillance. In this case, Vee holds the singular (and presently 
concealed) position of power. She assesses Chloë using the characteristic physical itemisation of the male gaze applied to female embodiment. She notices her "red hair," her "[c]lear skin of whipped cream," her fashionable outfit and "a body to be envied," and immediately judges her to be "too fashionable" and unsuitable for the job (81-82). From an historical racial perspective, Chloë as a representative figure of White South African female privilege is indeed liable to be considered "guilty". By implication, she is complicit in the racist state's collective subjugation of people of colour, even though the novel later revokes such easy assumptions. It is this racial privilege that Vee immediately addresses when her boss Portia informs her that Chloë badly needs a job and that she is therefore going to be her new assistant: "I'm fine with chances. But lots of people really need jobs. Plus they look like they actually need the money. Did you have to hire the whitest girl in the universe?' " $(83$, original emphasis). Portia rebukes Vee for her racism, but then immediately invokes race herself by reminding Vee that she, as a "half-white" person, has "the power to fire" Vee. Portia thus tries to mask the fact that she was forced by her superior to employ Chloë by playing the (reverse) equal chances card. When challenged by Vee, the Black migrant, who reminds her that in the new South Africa privilege still mostly runs along colour lines, Portia, the South African of racially mixed origins, is quick to assert her racial superiority.

Vee remains insistent and changes tactics by doubting that Chloë has ever worked a day in her life, as it "[l] ooks like the last heavy thing she lifted was a Barbie" (83). To her surprise, Chloë, once hired, disproves the Barbie image. She throws herself into the Paulsen investigation at once and proves highly efficient. Both Portia's and Vee's racial prejudices are exposed, their easy presumptions complicated. Despite Vee's initial misgivings about what she fears will be an "extensive baby-[sitting]" job (85), she soon comes to like and appreciate her young White assistant. When Chloë starts calling her mentor "bosslady", Vee is secretly pleased: "Bosslady. It conjured an image of a buxom authority figure swathed in the colourful lappa cloth of home, multitasking like an octopus and beating off with wooden spoons the ears of anyone who dared to be idle in her presence. She liked that. She ought to act more like it, now that she had her own personal slave" (137, original emphasis). As her fondness for Chloë grows, Vee responds by calling her "finegeh", which is Liberian pidgin for "finegirl". Chloë guesses it is an affectionate term "like 'meisie' in Afrikaans" (2015, 79), although the diminutive label "girl" also serves as a casually reminder of her inferior social position..$^{15}$ As age is a common social marker that confers

15 In the beginning, Vee even calls Chloë "Baby Gingernut” (Golakai 2011, 85, emphasis mine). 
authority in African societies, here Vee superimposes on the White Chloë her own cultural way of organising the social fabric. The "bosslady - finegeh" trope poignantly captures Vee's understanding of her hierarchical relationship with Chloë. It firmly establishes Vee's superior power position and her authority which is further underlined by the fact that Vee is a knowledgeable professional journalist and Chloë is not. Golakai's cunning recalibration of power relations is further exemplified by the way in which Vee takes on the role of protector for Chloë, whom she feels is in need of care. Being in the superior position for Vee not only confers privilege, but also, crucially, the obligation to act as a guardian. Vee takes this obligation very seriously. After their success with the Paulsen case, Vee uses her leverage with Portia to get Chloë a permanent job (Golakai 2011, 298). When they both move to the Chronicle, Vee makes one condition clear to her new boss Nico: "'Where there's room for me, there's room for her' " $(2015,15)$. She remains committed to providing this support (350). However, the serious argument that Vee and Chloë have towards the end of The Score reveals that Vee experiences her obligation to fight for and protect Chloë as a heavy burden and that she thinks that Chloë fails to see and appreciate how much work Vee is doing to save her in their competitive, even vicious, professional environment (279). Chloë, for her part, questions whether she can ever learn to fight her own battles when all she does is trail after Vee (278-279). Their argument revolves around the balance between dependence and autonomy, between control and protection, and testifies to the challenges of shifting power relations. At the same time, it shows that recasting character relations among female protagonists offers a productive space in which to test possibilities of new forms of social relationship.

Despite her own powerful position, Vee feels driven to contest Chloë's power of looking and knowing. The friendship between the two women almost reaches breaking point when Chloë reveals that she has been secretly investigating a sensitive issue in Vee's family history. Vee is enraged that Chloë has meddled in personal family matters that she has so far refused to share. Chloë recognises that she has overstepped the line, but complains that she feels excluded: she does not know where she stands with Vee and needs to understand "what kinda partnership" this is (2015, 281; see also 28o-282). Chloë perceives being allowed to look at the other, knowing the other, being let "in" (281), as an essential basis for trust-building in a relationship, but Vee does everything to thwart Chloë's inquisitive gaze. She goes on solo missions during their investigations and refuses to talk about her family with Chloë. While this behaviour is amenable to various interpretations, I would argue that Vee is contesting the power of the gaze, a power that defines who has the right to look at whom and who has the right to know whom. Vee's secrecy here functions like the Du 
Boisian veil that "deflects and refracts the gaze of domination from knowing 'the truth' of the submitted," as Munt reads it (1994, 117). As a Black foreign woman, Vee is sensitive to the gaze as a mechanism of control and domination. By being secretive and an individualist, she seems to be adhering to the archetypal isolated loner detective blueprint, but with Vee this acquires more complex nuance, for it works as a protective shield against the potential violence of the mastering, objectifying White gaze of the local. Vee's use of Liberian pidgin serves the same goal, obscuring herself and excluding Chloë. As Tina Steiner argues in her analysis of the use of Liberian pidgin in Golakai's novels, "The use of pidgin is a powerful device to assert cultural specificity and to withdraw linguistic transparency [...]. It also points to a convivial sociality from which locals are excluded due to their linguistic limitations [...]" $(2017,12)$. While it is not entirely clear why Vee, given her powerful position in relation to Chloë, would have to shield and defend herself, the use of pidgin asserts her difference and is aimed at distancing her from Chloë. Secrecy, not disclosing "the important stuff" (Golakai 2015, 103), for Vee is a distancing device. Overall, what we see in the relationship between Vee and Chloë is a powerful recalibration of received social positions. The relationship addresses key questions of where care ends and control starts, highlighting the thin line between protection and disenfranchisement, as well as issues of tolerance, naturalisation and assimilation. These concerns are at the heart of the power struggles not only in the arenas of race and gender, but in relation to foreignness. That such a reworking of social relationships in a South African context is imagined as initiated by an outsider calls attention to the hitherto unnoticed potential of African immigrants as agents for social change. Foreignness here is presented not merely as a question of being taken in by South Africa, but as prompting a realignment of power. For all its benefits, however, Golakai's focus on recasting power relations between Vee and Chloë forecloses the possibility of sisterhood. Even though at the end of The Score Vee decides to overlook the fact that Chloë has again failed to respect her privacy boundaries and starts to share some of her personal history with Chloë (354-358), they do not become "sistas". This becomes even more obvious when we look at another aspect of genre disruption in Golakai's detective novels: her inclusion of elements of chick lit.

\subsection{Crime Fiction cum Chick Lit: Strengthening Feminist Detective Agency and Disrupting Misogynist Generic Blueprints}

Like Makholwa, Golakai merges elements of chick lit into her crime fiction. The popular genres of crime fiction and chick lit share an engagement with gender issues, and both genres' potential for gender politics has been discussed 
along similarly controversial lines. ${ }^{16}$ My aim at this point is to examine how blending the two genres, as Golakai does, has the capacity to prompt interventions in the fields of race and gender. Specifically, I want to probe for tensions and synergies that may arise from combining the genres.

Pamela Butler and Jigna Desai describe chick lit novels as telling "clever, fast-paced stories about young, predominantly white women's messy journeys of personal and professional growth - heroines gain self-knowledge and selfacceptance, and are thus empowered to take control of their intimate relationships and professional lives" $(2008,2)$. When such novels are written by women of colour, "the characters' engagements with femininity and gender are often articulated through questions of race, nation, ethnicity, and socioeconomic class" (2008, 4). Demarcating chick lit from the romance genre, with the primacy that it accords to the male-female couple, Suzanne Ferris and Mallory Young maintain that "chick lit jettisons the heterosexual hero to offer a more realistic portrait of single life, dating, and the dissolution of romantic ideals" (2006, 3). Raymond Chandler, for his part, advises that a crime author jettison not so much the hero per se, but any romantic interests that he may pursue. He warns that "[l]ove interest nearly always weakens a mystery because it introduces a type of suspense that is antagonistic to the detective's struggle to solve the problem" (1962 (1949), 70). However, female crime writers usually disregard this and allow their heroines romantic attachments and a sex life, albeit that these may prove problematic. Rowe confirms Chandler's tenet in so far as her heroine's sexual agency seriously undermines her agency as a detective. By contrast, Golakai's turn to the conventions of chick lit works to complicate the assumption that love interests negatively influence the labours of detective agency. Vee's romantic liaison with Joshua Allen clearly furthers her investigations. She frequently discusses her cases with him, takes his advice and occasionally elevates his status from lover to sidekick (Golakai 2011, $282,2015,160$ ). Often this comes at some cost to him, as, for example, when Vee spoils their love-making with a sudden flash of investigative inspiration that needs to be followed up instantly $(2011,159)$. Rather than competing with the tension created by the investigation, such scenes add a delightfully humorous touch for the reader.

Besides assigning women a central role, authors of chick lit "present women as sexual agents" (Ferriss and Young 2006, 10). In her analysis of Ugandan and South African chick lit, Spencer demonstrates that "chick lit provides the space

16 Ferris and Young provide a brief overview of the controversy surrounding the feminist potential of chick lit (2006, 9-10). 
to reflect on and articulate women's desires" and allows them to assert the power of sexual negotiation $(2014,106)$. The crime genre, on the other hand, has a long tradition of criminalising female sexuality - for example, through the figure of the femme fatale. What is more, Black women's sexuality has been criminalised way beyond the crime genre. Hooks notes, "Traditionally, Hollywood's sexual black women are whores or prostitutes [...]" (1994, 65). White supremacist patriarchy has constructed them as "licentious" (66), as "she-devil[s]" (67) who lure and enthral men and are therefore in need of (White) male restraint. Against this background, blending crime fiction with chick lit opens up a space for rewriting female sexuality, especially Black female sexuality, and works to subvert both the generic frame of crime fiction and demeaning practices of representation more generally. ${ }^{17}$

This is the approach that Golakai pursues consistently in her depiction of her heroine Vee. At the beginning of The Lazarus Effect, we encounter a sexually frustrated Vee, following a lengthy period of emotional turmoil while she recovered from an ectopic pregnancy, an ovarian cyst and the messy break-up of her engagement to Titus Wreh (66-67). "Since re-entering singlehood" she sees sexy men everywhere and finds their "obliviousness with respect to their sexual appeal [...] practically malicious. Striding around displaying V-shaped torsos misted with sweat and bare, muscled legs ... it had to stop" (43). Vee's arch remarks here straightforwardly invert the traditionally male gaze on the Black female body, sexualising the men's embodiment for her own delicious pleasure. Soon afterwards, numerous opportunities arise for Vee, but despite her longing for intimacy, she carefully negotiates men's sexual advances. She says no to men many times, regardless of her previous history with them, and always finds her decisions respected $(2011,70,228,308,2015,145,213)$. Being able to choose is a source of liberation for her: "It was strange and a little funny. For the first time, she had two men in her life that she cared for fiercely, and yet, at her own choosing, her arms were empty. She didn't enjoy being alone, and saw no reason to be $[\ldots]$. But at times it was necessary. The situation needed to breathe" $(2011,228)$. When she is ready, however, Vee does not hesitate to take the initiative - and she thoroughly enjoys her erotic encounters, which are always focalised from her female perspective (2011, 205, 304, 2015, 154, 365). Unlike Persy, she experiences her sexuality as empowering and as a source of joy.

17 In a recent article, Rebecca Fasselt reads Golakai's novels as "chick-lit mysteries" (2019, 189). Fasselt claims they recast both the crime and the chick lit genre insofar as they subvert the quest structure that is inherent in both genres: the quest for a resolution of the crime and the restoration of order in the case of crime fiction, and the quest for romantic love in chick lit (189-19o). 
Drawing on Audre Lorde, African feminist Patricia McFadden boldly calls for the foregrounding of female sexual pleasure and choice and encourages women to embrace their "erotic power as a political resource" (2003, par. 7). Moving beyond postcolonial criticism, McFadden takes issue with the contemporary policing and surveillance of female sexuality in Africa by both women and men (par. 15, 17). The current discourses on female sexuality in Africa revolve around reproduction and the avoidance of disease and violation, and are a means to silence and delimit women (par. 15, 18). A redefinition of female sexuality that goes beyond these discourses is thus required (par. 23) in order to reimagine female subjectivity and to transform the social space at large (par. 7). Against the background of McFadden's argument, celebrating Black female sexual agency and eroticism through elements of chick lit becomes a feminist resistant act and disrupts the generic frame of crime fiction. Thus, Plain's claim about "criminal" White lesbian sexuality in crime fiction, where "the pleasures enjoyed by the detective herself will have repercussions far beyond the bedroom" (2001, 207), can also be applied to equally "criminal" Black female heterosexual sexuality in the genre.

Although Plain takes these repercussions to be positive from a feminist point of view, in the case of the White lesbian Chloë they are somewhat more ambiguous. Even though we first meet Chloë having sex with a certain Mr Cohen, her sexual orientation is made immediately obvious to us as readers. Promised a job by Mr Cohen, but horrified at now having to face his erect penis, she tells us that she is glad that she has no prior knowledge of heterosexual encounters: "Her feelings about [men] had been cemented early on in life and weren't likely to ever change" (Golakai 2011, 81). Vee never learns about Chloë's "carpet interview" (81), but Chloë openly displays her interest in women. Nevertheless, Vee remains blind to Chloë's sexual preferences until the end of the first novel, when she asks her assistant whether the tech guy who has helped them is her boyfriend. In response, Chloë tells her that the question is ridiculous because she is gay $(265)$. Vee is taken aback, even though "[i]n hindsight it was so obvious" (266). Unfortunately for Chloë, who would have liked to impart more to Vee, the moment of revelation happens when they are both in mortal danger, locked in the darkness of a tool shed by a murderer. Vee is busy trying to find a way out for them and only listens to Chloë's story with one ear. They soon manage to escape, and the moment is gone (269).

This is worth dwelling on, for the crime conventions here conflict with and override the chick lit generic features. Chick lit's emphasis on female friendship and female bonding (Spencer 2014, 92) gets marginalised by the plot requirements of the crime novel. Where chick lit would in all likelihood elaborate on Chloë's intimate revelation through female conversation, crime fiction, driven 
towards final resolution, has no space to develop and deepen such details, which are pushed to the side. All that Vee offers at this moment lies within the limits of her obligations as bosslady; she promises to protect Chloë at work (Golakai 2011, 266). The only other time Vee makes a reference to Chloë's sexual orientation is in The Score, when she warns her not to sleep with one of the female suspects (147-148). It seems that Vee is strangely reluctant to talk about female same-sex sexuality. When she does, Chloë's lesbianism is defined as a problem that must be kept from Portia, and that must also be kept in check. Vee occupies the hegemonic phallic position here, which is anomalous given the heterosexual liberties that she herself enjoys. The genre of chick lit would allow her to take a more straightforward and a more sisterly approach here; after all, she and Chloë find time to discuss Vee's own amorous adventures and relationship issues in the midst of their busy detective lives $(2015,67-69 ; 148)$. Vee's reticence with regard to Chloë's transgressive sexuality may be another distancing strategy aimed at maintaining the superior position that she occupies in her relationship with Chloë, which would be undermined by an invocation of chick lit's political potential for nurturing female friendships. Alternatively, there is a possibility that Vee is distancing herself from the potential threat of Chloë's lesbian sexuality per se. Does Vee have to abject Chloë so as to avoid confronting her own suppressed lesbian desire? At this early point in Golakai's series, the question remains unresolved. There is no textual evidence to suggest that Vee's inability to decide between her two male lovers Joshua and Titus is testament to a frustration with heterosexual desire. Likewise, even though Chloë is very fond of Vee and is aware of her attractiveness - at one point, she notes that Vee has a "dirty beauty" and a face that makes "men look, and look again. At certain angles it spelled trouble, and could suck you into wanting to find out how much" $(2015,69)$ - there is no indication so far that she is sexually interested in Vee. In any case, this is a space to watch as the Vee Johnson Mystery series continues.

What is disturbing in the light of Golakai's otherwise progressive gender politics, however, is the fact that at times Chloë herself seems to take the hetero-patriarchal position. In a bout of relationship frustration, she calls women "evil, twisted sirens" who can "crush you like a cockroach" $(2011,180)$. Later on, she displays self-hatred and reinforces the trope of the monstrous woman by applying it to herself. She suspects her sexual orientation to be the reason that her circle of caring female friends is dwindling. She muses that "perhaps women were right to be antsy, seeing as her sexual preferences made her a monster to be feared" (232). Chloë's internalisation of patriarchal sexism and homophobia jars with Golakai's otherwise very successful strategy of mixing crime fiction with elements of chick lit, which not only serves feminist 
political ends but disrupts the generic blueprint for crime fiction. The effect of this goes far beyond simply "jazz[ing] up the entertainment value" of her novels (Naidu 2013b, 734). Chick lit puts women into the limelight, depicting a cast of predominantly female protagonists, and is largely written by and for women. Golakai transfers this centrality of women to her detective novels. Not only does she populate them with an abundance of professional women, but she assigns to women all three pivotal roles in the crime genre. Golakai writes female detectives, but women also feature prominently as perpetrators and victims, as we shall see when we look at the kind of "truth" and justice that Vee establishes as a detective agent.

\section{$3 \cdot 3$}

The Outsider's Detective Gaze: Finding Conflicting Truths, Achieving Limited Justice

Prior to studying Vee's cases and the kind of justice that she administers by solving them, we need to consider the justice that comes from having a migrant detective per se. In my view, imagining the detective gaze as that of a foreigner is in itself a source of alternative justice in Barbara Hudson's sense. In the South African real, Vee herself, as an African immigrant, would normally be the one facing interrogation and scrutiny. What Golakai does in her crime fiction is turn the tables: she has her detective heroine subject South African society to her gaze and her questions. In this way, she integrates the one who is normally outside the constituency of justice; fulfilling the requirement that justice be discursive $(2012,388)$. According to Hudson, "[a] major theme of feminist and post-structural, post-colonial critiques [...] is that established liberal justice suppresses the voice of the outsider" (389).

By integrating the outsider's voice - and gaze - Golakai also achieves what Steiner, with reference to Viktor Shklovsky, terms a "defamiliarization" (2017, 3 ) that "exposes reified structures of relation" (1). This extends to gender, too. When in The Lazarus Effect Vee is watched and later pursued and run down one night by an unidentified driver in a Mercedes, readers automatically assume that the culprit is male; Vee herself fleetingly thinks of Lucas Fourie (221, 228-230). But the driver turns out to be Rosie Fourie, the very woman who killed Jacqui. In the end, Vee admits, "I made the biggest mistake by assuming this had to be a man's crime" (279). When Vee's home is broken into at night and she is brutally attacked in The Score, the reader is likely to picture the assailant's "hefty" human body (174) as that of a man. When Vee's boss Nico is told about the attack, he, too, worries that the "man" could have killed her (180). Given her physical contact with the attacker, however, this time Vee is sure it was a woman. We later find out that it was Xoliswa, the murderer of both Gavin and Rhonda. By defamiliarising the attacker's gender, here Golakai 
deliberately plays with and renders tangible the gender bias that tends to govern how we respond to criminal acts.

Race also undergoes defamiliarisation. Steiner provides a detailed discussion of the defamiliarising effect of Golakai's use of humour and irony that functions to "probe racial categorization" in South Africa and to debunk racial bias on all sides in inter-cultural encounters $(2017,14-17)$. An outsider's gaze is needed for the disarming directness and humorous audacity with which Golakai alludes to and remoulds apartheid categorisations. Take, for example, Vee's comments on her boss Portia's curly, cinnamon-hued hair. According to Portia, "her hair guaranteed she was coloured" (Golakai 2011, 39). Vee, however, is sure that the "real lesson" is a different one: namely, that "her hair and dress code gave vital clues as to her mood. Curly and up was bad [...]" (39). When Portia, despite these portents, likes Vee's proposal for an article, Vee notes with relief, "Luckily, Portia's coiffed hair signalled a playfully combative, but not spiteful, mood" (42). Her own reinterpretation of the hair as signifier is thus modified, its meaning unmasked as notoriously arbitrary and unstable. There are other ways in which Golakai defamiliarises the gaze. The following scene, just prior to Chloë's interview with Tamara, a former friend of the missing Jacqui, is a case in point: "Tamara finally wandered back with a cup of Mugg\&Bean coffee and a box of confectionery. Chloë pasted on a polite smile as the leggy, cookie-coloured girl, her height boosted by a pair of weapon-toed boots, eyed her up and down. For the second time that day, Chloë Bishop felt too short and too white" (110). Despite the fact that Chloë is the focaliser, the power of the gaze here lies with the woman of colour, Tamara, who eyes Chloë "up and down." Tamara renders Chloë the object of her gaze and thus changes the power relations. From her position of power, Tamara is the one who defines what is "normal", prompting a feeling of inadequacy in Chloë, who suddenly feels "too short and too white." Besides recasting power, Tamara's gaze makes Chloë's generally "invisible" white skin a visible colour. The same can be said of Vee's gaze on Chloë, as we have seen. In his study on the representation of Whiteness in film, Richard Dyer argues that "white is no colour because it is all colours" $(1988,45)$, and that it is precisely this characteristic of being everything and nothing that allows White people to "colonise the definition of normal" (45). According to Dyer, "The colourless multi-colouredness of whiteness secures white power by making it hard, especially for white people and their media, to 'see' whiteness. This, of course, also makes it hard to analyse" (46). Whiteness requires a comparative element so that it can be studied - a colour is required to make it visible (47). Thus, making White visible and open to enquiry is a means of securing justice. It is as significant an achievement of Vee's detective gaze as her exposure of racial and gender stereotypes. 
When it comes to the dead bodies of the victims whose murders she is investigating, however, Vee's detective gaze is severely limited. In the first novel, Vee never actually gets to see Jacqui's dead body. The only way she "perceives" her is as the effervescent "Air Girl" in her visions (Golakai 2011, 26). During these visions, it is more a case of the Air Girl looking at Vee than the other way around: "[W]ith head cocked to one side, for a few moments she regarded Vee's prostrate form as if it were some pathetic animal. Then she looked over her shoulder several times, beckoning with a hand" (13). In an authorial move that throws into sharp contrast the limits of the detective's gaze, readers are granted exclusive access to Jacqui, both dead and alive. At the beginning of the novel, and again later on, our attention is directed to the location of the teenager's "corpse" (9) in a dry storm drain, and to the ways in which it has been vulnerable to the elements and subjected to a process of mummification $\left(9^{-10}, 143\right)$. At the end of the novel, we return to the body in the dream of a dying street child, who dreams of his encounter with the Jacqui on the night she was dumped in a drainage canal. Through the street child's empathic gaze, we see the terror in Jacqui's eyes: "It looked like a human being. [...] a girl, or a boy with a pretty face and lots of hair" (302). In addition, at regular intervals readers are privy to a number of flashbacks featuring what turns out to be Jacqui's last day alive.

In The Score, it is not so much Vee's gaze as her right to see that is questioned. She looks hard at the bodies, closely, though it is in no way a sensationalising or eroticising interest. Instantly recognising Gavin, she screens his clothes for traces of mud and - as he is dangling from a coat hook - for signs of strangulation $(1,3-4)$. Hers is a tentatively objectifying detective gaze, but it is dominated by her own fears of being incriminated. The look that she takes at Rhonda's dead body in the same novel is not predatory either, but it is a "forbidden" look, in the sense that she knows that she is not supposed to interfere with the police investigation. For this reason, she urges the servant who showed her the body not to tell anybody that she has seen, let alone photographed, Rhonda's corpse (48-54). As in The Lazarus Effect, readers are given an extra look at the body in question. The novel's final scene reveals the existence of a secret, so-called nanny camera that was hidden inside a glass figurine in Rhonda's room. Through the camera's eye, we witness Rhonda's last moments alive, how Xoliswa chokes her with a pillow and then rearranges the scene to give Rhonda's death the appearance of a suicide. Finally, we see the maid who discovers Rhonda and Vee who examines and photographs the body (371-376). Besides creating suspense in the crime narrative, the extra information in both novels is evidence of Vee's detective skills and functions to confirm her agency as a detective. As such, it does justice to the dead victims. The existence of Jacqui's 
physical remains and the flashbacks to her last day alive provide the (material) evidence for Vee's visions, which might otherwise be dismissed as the hallucinations of a deranged person. They also support Vee's intuition that Jacqui has not simply run away. Likewise, the nanny camera footage confirms Vee's findings and proves the official police version of events wrong: Rhonda did not commit suicide. At the same time, the extra information renders visible the limited frame of the detective's gaze and limits it further. The right of the outsider detective to look at the dead body is denied (Jacqui) or her actions are portrayed as illegitimate (Gavin and Rhonda). What is more, the detective herself comes under scrutiny, as she is subjected to both the Air Girl's counter gaze and the eye of the nanny camera. The camera's hidden eye incriminates and frames both the real murderer, the Black woman Xoliswa, and the Black detective's forbidden act of looking at Rhonda's dead White body. Golakai's critique of race and gender relations is also compromised, as the nanny camera footage is in the hands of Trevor Davis, the Coloured male concierge at Grotto Lodge. His threat to keep it as potential leverage for "a rainy day" is disturbingly left dangling over the Black women at the end of the novel, potentially framing them $(376)$.

The question remains as to what kind of justice is served by Vee's investigative work and the truths that she uncovers. Vee's first case, investigating the disappearance of the teenager Jacqui Paulsen, taps into the sadly common phenomenon of missing children in South Africa, ${ }^{18}$ which Vee uses as a pretext to secure her boss's permission to write an article. It turns out that Jacqui was murdered by her half-sister Rosie, who then disposed of the body with the help of her older sister Serena. What Vee uncovers in the course of her investigation does nothing to illuminate the real plight of missing children or the conditions that facilitate their disappearance in South Africa, but it put the spotlight on children as both victims and perpetrators in conflicts or wars that are only partly their own - if at all. However, although the novel debates the question of the responsibility and moral accountability of teenage children for their actions by portraying them as both victims and perpetrators in a crime story, it presents us with discordant answers. According to Vee, the detective, Rosie ran over her half-sister Jacqui with her parents' car in "a moment of madness," because she felt let down by Jacqui and believed that she was going to wreck their family (Golakai 2011, 287). Rosie, had come to view Jacqui as the ally she badly needed, as the rest of the family made her feel that she did not really

18 Orford has her detective heroine Clare Hart investigate this phenomenon in Daddy's Girl and Water Music. 
count (280). However, she felt betrayed (281) because Jacqui started bonding with Serena and because she wrongly suspected that Jacqui was pregnant by her brother Lucas (286). In Vee's opinion, Rosie was motivated not just by anger, but by the fear that Jacqui would destroy her already fractured family "all over again" (286).

What Vee construes as an argument between two half-sisters and as an attempt to protect the family happens against the following background. Dr Ian Fourie, a famous Cape Town cardiologist, has four children with his German wife Carina, a paediatrician: Sean, Serena, Lucas and Rosie. At the same time, he has a daughter with Adele Paulsen: Jacqui, who is the same age as Serena. Adele was Ian's girlfriend before he went to study abroad. When they met again many years later, they had an affair and Adele fell pregnant. Ian, now a husband and father-to-be, asserted his patriarchal authority (52) and coerced Adele into complying with his "grand plan concerning his two families [...]: he had two families and they would stay separate. I'm sure you're aware this kind of thing happens all the time" (53). When Adele tells Vee about this arrangement, she is not surprised. "Big house, small house. Vee was very familiar with it, having grown up in a similar set-up. It was as old as the hills and a virtually indestructible pillar of the African family structure" (53), she informs us, thus anchoring the South African Ian Fourie's actions and decisions within the larger African practice of polygamy. Ian's plan to keep his two families apart fails because his oldest son, Sean, develops leukaemia and the only one who is a match for a life-saving bone marrow transplant is his half-sister Jacqui. Ian demands the secret collaboration of Adele and Jacqui (now 12 years old). Adele agrees on condition that Ian finally tells his wife Carina about her and Jacqui, which he does (54-55). Sean and Jacqui are being prepared for the transplant when Adele loses her nerve and temporarily takes Jacqui home. By the time Adele gives her consent for Jacqui to resume the process, Sean has developed an infection, which he dies of (56). His death effectively breaks his mother Carina. She never forgives Ian for his affair with Adele and their marriage crumbles, even though they stay together. Jacqui, however, can no longer be forced to stay away from the Fouries: "she wanted to be part of them so much" (57).

In the light of this larger system comprising the family and the "big house small house" model that undergirds it, Rosie's murder of Jacqui takes on a different dimension. What Vee uncovers about Ian Fourie and his two families reveals the sheer futility of either Rosie's attempt to protect the family or Jacqui's efforts to become part of it. Too many adults have failed on the way: Ian by enforcing his patriarchal "big house - small house" model, Adele by jeopardising the transplant process and Carina by absenting herself emotionally from her other children. By refusing to resolve their conflict or at least to address 
it openly, the adults harm their children and pave the way for the fateful sororicide. As Jacqui reflects to Rosie before she is run over, "Nobody tells us anything, Rosie, not you and not me. Live with it'" (292). Even once Jacqui is dead, the sisters try to deal with the murder by themselves. Serena organises a car, and they secretly dispose of Jacqui's body. These complicated plot twists may cater to the generic need for spectacle and, at times, distract from the truth-finding process. Yet insofar as the novel draws into focus the bigger frame - that is, the failures of the adult world, including the patriarchal family structure as upheld by Ian, with the complicity of Carina and Adele, ${ }^{19}$ it can be considered a successful attempt at truth-finding. Looked at closely, Rosie's actions as an individual are accounted for in interaction with broader structures, which Posel sees as a prerequisite for successful truth-telling $(2002,159)$. This is in keeping with the importance that she attributes to "understanding why individuals act the way they do by inserting their actions into a broader causal context [...]" (159, original emphasis). Moreover, Jacqui the victim is imbued with agency both through the role that she plays in provoking Rosie and, after her death, through her appearances to Vee as a spirit. Responsibility and culpability are presented as relational, a principle that Hudson identifies as crucial in her outline of an alternative, more inclusive notion of justice $(2012,392)$. Without excusing Rosie, the novel lifts a substantial part of the responsibility from the children's shoulders and shifts it to where it primarily belongs: namely, with the adults and the patriarchal family structures that they reproduce. In this way, the novel allows for an exposure as well as for a modification of the limits of formal justice.

These limits are exposed further by Golakai's integration into the novel of Vee's traumatic experience during the Liberian Civil War (Golakai 2011, 255258). Locked up by Rosie in the darkness of a tool shed, Vee relives how she killed a child soldier who threatened to rape her when she was taken captive by the rebels (258). Back then, she was only a "little girl" (255), the soldier a "boy" who was "old, but not old old - maybe five years more, like her brother" (258, original emphasis); they were both caught up in a war that was not theirs. The two children both perpetrate crimes, yet they are also both victims of the larger crime that is war. Criminal justice fails to account for such moral

19 Both Carina and Adele become complicit as neither of them openly challenges Ian or the system as such. As financially independent professional women, both have the means to resist Ian, but instead they take out their anger and frustration on their children - Adele by refusing to collaborate fully in the transplant, Carina by emotionally abandoning her children after Sean's death and by allowing her bitterness towards her husband to poison her children's home (Golakai 2011, 146). 
complexity and the concomitant questions of responsibility. Further outside the bounds of the formal justice system, if not society itself, is the street child, whose perspective and voice Golakai includes towards the end of her narrative. The "watcher" (10, 300) whom we met in the novel's opening scene, when he was waiting for Jacqui's remains to resurface from the storm drain after the rain, is now himself dying. He is dreaming of how he realised that Jacqui was still alive when Serena and Rosie dumped her, of how he stayed with her, making sure that she did not have to die alone, and of how he tried to alert the police, but was not believed, his account being rejected as storytelling "while high on tik" (303). By including him, the outsider who is discredited by the police, by acknowledging his existence and by giving him credibility - Jacqui's remains are indeed found, later on, in the place that he indicated - the novel fulfils the demands for a more inclusive kind of justice, in keeping with Hudson's principle of discursiveness $(2012,389)$. Yet at the same time as the novel opens up such spaces for alternative notions of justice, it forecloses them. Despite unveiling a larger picture during her investigation, Vee finally settles for a narrow interpretation of Rosie's motives. When Chloë concludes, after she and Vee have gone over Rosie's and Serena's statements, "'That's so ... despicable and sad.' [...]. 'They were just two stupid kids having a typical stupid argument'" (Golakai 2011, 294), Vee does not contradict her. Nor does she question the kind of formal justice that will be administered to Rosie and Serena - justice that she was instrumental in bringing about. She states, "This will be the blow to destroy them forever: Serena and Rosie have practically screwed up their whole lives [...]'" (296). While their children are punished, either with death (Jacqui) or by the criminal justice system (Rosie and Serena), the adults all get away with their crimes (309-310). In terms of justice, the reader is thus left with a discomforting paradox. While the novel imagines an inclusive sort of narrative justice, in the end it nevertheless gives in to and reproduces the status quo of the real.

In The Score, Vee's investigation into the murders of Gavin and Rhonda, which happen at the Grotto Lodge in Oudtshoorn during a conference on government incentives for private entrepreneurs, almost instantly reveals the larger structures of corporate and state-corporate crimes that frame the two murders. Vee establishes that Gavin was murdered by Xoliswa Gaba, a highly talented software developer and former employee of Berman \& Moloi Financials, a company owned by Gavin and his partner Akhona Moloi. Xoliswa had developed an evaluation software, which Gavin and Akhona monetised and promoted without crediting her, thus effectively stealing her intellectual property and its associated benefits (338). At first, Xoliswa pressures Gavin and Akhona for financial compensation. Later, she takes revenge by murdering Gavin, 
along with Rhonda, the lodge's deputy manager, who was in the wrong place at the wrong time. Crucially, Akhona, frustrated at having been sexually rejected by Gavin, manipulated Xoliswa's revenge by feeding her information, but did not think that Xoliswa would go so far as to kill Gavin (341-342). Once Vee arrives on the scene and starts probing, Akhona manipulates her into exposing Xoliswa in order to deflect attention away from her own illegal machinations. What moves on to Vee's radar in the course of her detective work is the way in which government corruption goes hand in hand with corporate crimes and the exploitation of low-ranking employees (Golakai, 239-240). Semi-legal and illegal business practices such as undercutting the minimum wage by commissioning "freelancers", inflating quotes and denying workers their salaries are facilitated by corrupt state officials (240). This revelation has a sobering effect on the Liberian Vee, who realises that business practices in South Africa, the place of dreams for so many other African nationals, are on a par with the "shenanigans from my corner of the continent" (247). Other than locating South Africa in the wider African context of corruption, Golakai's novel adds little that is new to the representation of state-corporate crimes, a problem addressed frequently both in South African crime and true crime fiction in the South African media. ${ }^{20}$

What the novel stages convincingly, however, is the blurring of any neat boundaries between victim, perpetrator and detective, thus allowing for the ethical complexity and questioning that is conducive to inclusive forms of justice. It does so mostly through the figures of Vee and Xoliswa. Xoliswa has much of the destructive agency of the perpetrator. She has a history of physically attacking people and, as Vee experiences first hand, she fights "[...] dirty. Ghetto kinda dirty" (180). She has killed two people, one of them innocent, and, if Vee had not managed to stop her, she might have killed a third, Vee's neighbour Tristan, a boy of 11 . At the same time, she is also a victim of the criminal machinations of her employers, so that at times Vee feels sympathetic towards her (216). She also admires Xoliswa's skills, to some extent (276), and is shocked to hear of her suicide (323). Writing Xoliswa as both perpetrator and victim not only complicates questions of guilt, but works against freezing her in either the stereotype of the Black female criminal or that of the Black female victim. Recalling Adelene Africa's study on limiting conceptions of real female perpetrators as mad, sad or bad (2010, 80), we notice that Akhona taps into this discourse when she describes Xoliswa to Vee as a psychopath with drug issues

20 See, for example, Mike Nicol's Revenge Trilogy and Mandy Wiener's Killing Kebble (2012). State-corporate crimes such as the Arms Deal and "Guptagate" are regular features in the South African media. 
(Golakai 2015, 294). Even though Vee recognises that Xoliswa has psychological challenges, she has reservations about dismissing her in this manner. After Xoliswa's suicide, Vee finally succeeds in exposing the extent of Gavin's and Akhona's fraud. This proves that Xoliswa had real cause for anger, as she was indeed deceived and robbed by her employers: "They left me nothing. Nothing do I have left, you understand?' [...]. 'I handed everything to them on a plate, my ideas, my creation, and they [...] played me for a fool. Right under my own nose [...]'" (311, original emphasis). The allegations that Xoliswa had made all along were not the ravings of a madwoman: "Now Vee understood the seat of Gaba's outrage, her inability to let sleeping dogs lie. They'd excised a piece of her soul and gone running" (338).

Yet in the end Xoliswa kills herself over the injustice done to her (334). Despite the fact that the novel allows for a differentiated view on Xoliswa and, by doing so, serves a kind of justice that is in keeping with Hudson's principles of relationality and reflectivity, it sacrifices Xoliswa while the larger criminal structures stay in place. Through her suicide, Xoliswa anticipates and reifies the punishment meted out by the state's criminal justice system. What is more, Vee is partially responsible for this sacrifice. As a detective-journalist, she is implicated in the crimes against Xoliswa. It dawns on Vee that she herself has been no more than another player in Akhona's scheme. Akhona had deliberately set her on Xoliswa's trail in order to further incriminate Xoliswa and deflect attention from herself. Intent on a news scoop as Vee was, she unwittingly became complicit in Xoliswa's death. She realises, "I should've connected the dots. Akhona strung me along, strung me up, yet I didn't see it. She made me before I made her, smelled the hungry journalist vibe and fed it' " (340, original emphasis). As the dispenser of the justice that she has served by shedding light on the "truth" behind Xoliswa's claims, Vee herself has to face scrutiny. She is forced to admit, "'We are all the bad guy! Me, you, Gavin, Moloi. Even Xoli ... if she'd just gotten out of her own goddam way and asked for help' " (343-344). Here Vee is confronted with the effects of her work and with the kind of justice that it achieves. She has to acknowledge that, as a journalist, she is prone to being instrumentalised by the wrong party. Investigative journalism can work as a means of alternative justice, but it can just as easily become criminal, reinforcing a conventional form of criminal justice that has been hijacked by a criminal society. There are also questions as to its effectiveness. Vee's colleague Darren offers a scathing judgement. According to Darren, journalists can "dig all this [crime] up" and trigger "an avalanche of articles," but eventually people will be "desensitised and it will die" (249). The novel acknowledges the complicated position that the investigative journalist occupies vis-à-vis questions of justice and the justice system - as does Vee herself. When reminded by her 
boss, "'You're a journalist, Johnson, not a crime fighter. You chase stories to boost circulation. You don't save lives' " (346), she is unable to draw such clear lines and is not comforted. Studies on the real impact of investigative journalism suggest that her discomfort is justified. For example, Roxana Galusca finds that investigative journalism in the US with regard to sex trafficking forms a questionable "regime of truth" $(2012,1)$. Since it excludes the migrant women concerned, it is not in a position to address the complex realities of their lives (16). Galusca's analysis reveals that the anti-trafficking discourses employed by US investigative journalists are "not simply humanitarian"; rather, they are "always already imbricated with institutional and noninstitutional forms of power, as well as wielding and producing new effects of power" (16). Golakai's novel serves to raise awareness of such potential imbrications in South Africa.

With her Liberian investigative journalist Vee Johnson, Golakai has successfully written herself into the South African crime fiction scene. As she has established Vee in both the global generic and the local South African frame, she has significantly revised the perception of those frames. Her empowered, gutsy, stylish female African migrant detective in Cape Town signifies a radical recasting on various levels. She is the Black woman who secures herself a place inside the institution of the "serious" media, which is still cast as predominantly White and male. She is also the Black foreign "bosslady" of the White local "finegeh" sidekick. Rather than allowing others to have her under their surveillance and to render her a visual object, she reserves to herself the power of the gaze and scrutinises patriarchal family structures as well as the corporate world. As one who embodies the traditionally invisible and marginalised, she makes visible criminal structures, as well as the dominance of Whiteness. She rewrites the stereotype of the female migrant victim as a more empowered script that involves gender mobility and moving towards more appropriate and complex forms of lived justice that are not accommodated by the current system. Instead of writing about sexual violence wrought upon women, Golakai writes a sexually empowered detective. Rather than having the generic frame contain crime, she disrupts the frame with both a criminal detective and elements of chick lit. However, although Golakai's interventions with regard to race and gender are generally successful, some inconsistencies remain. While Vee's agency as a detective serves to rework the stereotype of the Black female criminal, the sacrifice of Xoliswa in The Score reifies it. For Xoliswa, victimhood prevails: her disruptive criminal energy is contained through her suicide. In a similar vein, chick lit functions to strengthen the gender politics of the crime novel, but its emphasis on empowering sisterhood is subordinated to the project of rewriting established power relations. Moreover, the subversive act of celebrating Vee's heterosexuality is compromised by the narrative repression of 
Chloë's homosexuality. Finally, Vee's at times inhibited, criminalised detective gaze limits her empowerment and potential for administering more inclusive, restorative modes of justice. Justice is served by Vee, as her investigations reveal the effects of patriarchal family structures and female complicity in them (in The Lazarus Effect) and the ways in which criminal state-corporate structures violate lower-ranking staff (in The Score). At the same time, the novels allow for much narrower interpretations that blank out the larger structures and present the murders as the result of jealousy between individuals. Such ambiguities threaten to reproduce hegemonic structures, also with regard to justice. On the plus side, they at least militate against neat generic closure and allow for a narrative marked by moral complexities. Overall, the contradictions in the Vee Johnson Mystery series contribute to Vee's strong and refreshing presence as a character who introduces an innovative "pan"-African element into the writing of a South African imaginary. Hers is a unique perspective from both within and beyond South Africa's borders. The Score, in particular, initiates a meditation on the kind of justice dispensed by investigative journalism - a question that is also central to Charlotte Otter's Maggie Cloete Mystery series.

\section{Renegade Contained: Charlotte Otter's Investigative Journalist Maggie Cloete}

This was exactly why she stayed in crime. She couldn't write about James Bond movies or ballet or diabetes when degenerates out there were preying on the smallest, weakest and most vulnerable members of society. She wanted them found and put away and left to rot.

MAGGIE in Balthasar's Gift (121)

When Charlotte Otter's fearless heroine Maggie Cloete guns the engine of her "Chicken", a 1998 Yamaha XT 350, and roars down the streets of Pietermaritzburg, the signal she sends to wrongdoers is unmistakeable. Maggie, a White woman, leaves no stone unturned in her determination to find them and effectively uses her sharp journalist's pen to expose them, thus providing justice for their victims. Like Rowe's detective protagonist Persy, Maggie works on home turf in Pietermaritzburg, where she was born and bred. This town was also once home to the author, who now lives in Germany. In this chapter, I will investigate the nature and politics of Maggie's agency as a detective. I will argue that this tough, confrontational and openly resistant investigator differs from Persy and Vee in that her powerful rage is as much a strategic gender 
performance as it is the motivation behind her actions, coming to resemble the kind of masculinity performed by the female perpetrators.

Maggie's first case in Balthasar's Gift (2014a), set in Pietermaritzburg at the turn of the millennium, is the murder of AIDs activist Balthasar Meiring. It brings to light not only that Balthasar was murdered by his father Lourens Meiring, but also the dark chapter in South Africa's recent history commonly referred to as "AIDS denialism", which grew under Thabo Mbeki's presidency. Otter thus shares Lorimer's focus on non-spectacular, structural violence and the racist and misogynist frames that sanction it. Karkloof Blue (2016b), which is set in the same town fourteen years later, moves far beyond the endangered butterfly of the book's title. The narrative traces various crimes emanating from Sentinel, a local forestry company, and those associated with it. Some of these crimes go back to the 1980s and South Africa's apartheid past. Maggie's investigations are motivated by her strong and successful commitment to justice. With the journalist's pen as Maggie's weapon, Otter's detective novels, like Golakai's, offer reflections on investigative journalism as a means of achieving justice. While Maggie is able to provide a more inclusive kind of justice, especially with her renewed attention to cases that were prematurely closed by the formal justice system, ultimately her endeavours remain contained by the very same system.

Charlotte Otter was born in South Africa and grew up in Pietermaritzburg, near Durban. Like her heroine, she is White and has a background as a journalist, having worked as a crime and court reporter for various South African newspapers. In 1996 Otter emigrated to Germany. She now lives in Heidelberg (KZN Literary Tourism 2015, par. 1). Balthasar's Gift is her critically acclaimed first novel in the Maggie Cloete Mystery series. The novel was first published by Aufbau Verlag/Ariadne in German translation in 2013 as Balthasars Vermächtnis. The English edition was published in South Africa in 2014 by Modjaji. The second novel in the series, Karkloof Blue, was again published first in Germany (2015) and then in South Africa (2016). It, too, has received enthusiastic reviews. Currently Otter is working on her third Maggie Cloete Mystery, entitled Durban Poison. As the author details, she writes her novels in English and then reworks them in collaboration with her translator Else Laudan of Ariadne, who has been publishing crime fiction by women as a feminist project for over twenty years. At the end of this process, the changes are fed back into the English original (2016a, par. 12). The inter-cultural genesis of the Maggie Cloete Mystery novels, which involves cross-fertilisation between the English and German versions of the texts, is in itself a topic worthy of exploration, although it is beyond the scope of the present study. Otter is explicit about wanting to join the ranks of feminist crime writers. The label "feminist crime 
fiction" features prominently on both her website and her Twitter account, and Otter calls herself "an angry feminist" who embraces the label (2014b, par. 45). I read the creation of her heroine Maggie as part of her feminist impulse.

\subsection{Doing Angry Female Masculinity as a Detective: a Feminist Resistant Act?}

Maggie is introduced to us in a spectacular stunt in the opening scene of Balthasar's Gift. When she witnesses the robbery of a female market trader while waiting at the traffic lights on her way to work, Maggie immediately guns her motorbike and sets off in pursuit of the thieves, subsequently following them on foot through alleys and over rooftops until she manages to tackle one of the men, wrestles with him and gets hold of his knife. Just before she ties him to a lamp post with the laces of her steel-capped Docs, she receives a call from Zacharius Patel, her boss, who dispatches her to the scene of a shooting at HIV House (7-10). The episode effectively establishes Maggie's key characteristics: she is an intrepid, tough, determined, lone warrior hero, who does not hesitate to throw herself into a physical fight with men if necessary. Like Persy and Vee, she embodies the generic male detective script as a woman. Maggie is both an efficient crime fighter and a respected journalist who works in and is framed by a male-dominated environment, initially as a crime beat reporter and later as a news editor for the Pietermaritzburg Gazette. However, her performance of masculinity goes beyond her professional role and is more ostentatiously angry than that of the other female detectives examined so far. Arguably, her rage over injustices is as much the driving force behind her actions as it is a strategic masculine gender performance. "Doing rage", as well as "doing detection", is her way of "doing masculinity", which very nearly leads this detective to "doing crime". Since Maggie is reminiscent of the female perpetrator, my reading of her agency draws on Judith Halberstam's work on both female masculinity and the expression of rage as a resistant strategy, as a political response (Halberstam 1998, 1993).

The most obvious aspect of Maggie's masculine demeanour, her trademark, is her favourite ride, a motorbike nicknamed "Chicken". Chicken represents a visible means of the "cultivation of female masculinity" (Halberstam 1998, 272 ). What is more, it is a celebration of a particularly aggressive, rebellious kind of masculinity. Maggie enjoys nothing more than gunning her bike, be it in her free time or on professional missions. She regularly exercises Chicken on the plantations, her "off-road playground" (Otter 2014a, 201). "Screaming up the highway," doing "[s]ome good healthy lorry-dodging" (34), allows Maggie to let off steam and process emotional turmoil (2016b, 188). It is the kick she craves as an adrenaline junkie, the "rush of freedom, the thin line between life and 
death" (51). Even a potential lover's mettle is tested by taking him on a scary ride on the Chicken (201).

Maggie looks and acts the man in other ways. While she is heterosexual, the combative, short-haired journalist has the looks of a "butch" (109) and is treated "as one of the boys" as soon as she enters the Alpha Garage run by Piet (2016b, 46), who "like[s] to imagine her combating criminals at every turn" (2014a, 146). Her "uniform" consists of "black t-shirt, cut-off jeans and short Docs" in summer (2014a, 48) and an equally black long-sleeved/long-legged outfit, supplemented by a fleece and motorcycle leather jacket, in winter (2016b, 37-38). An expert on cars, she also has a reputation for abusing them during car chases with criminals $(2014 \mathrm{a}, 113,155)$. She is a drinker who likes her drinks strong (2014a, 62, 2016b, 99), tends to wolf down her food (2016b, 53) and fights pain with pain $(2014 a, 75)$. In an interview, Otter describes Maggie as "a crime reporter on steroids [...]. It's just that she's a Maggie, not a Mark" (Otter 2014b, par. 23, 42). Maggie also acts the male part within the family. In the absence of their parents, she is the provider for her war-traumatised brother Christo, thus taking the traditionally masculine role. In between the two novels, Maggie becomes a mother, but for the duration of Karkloof Blue her 11-year-old son Leo conveniently stays with his father in Johannesburg. Clearly, Maggie's maternal side is not (yet) an issue that Otter wants to explore.

Maggie's resistant agency is infused with an anger that is not characteristic of all female detectives. Rage over injustice is what spurs her criminal investigations. Anger at being compromised by male criminals and bosses alike triggers the fight in her and leads her to attack verbally and physically - time and again (Otter 2014a, 9, 115, 173, 188, 225, 2016b, 43, 77, 84, 106, 206). When she narrowly escapes a kidnapping and is rescued from a crashed car in Balthasar's Gift, Maggie does not feel relief, but anger: "Her head was pounding and her body felt weak, but a new energy was coursing through her. It was her old friend, anger, icing her body so that her teeth chattered" (163). In this particular example, Maggie is incensed as much by the fact that the criminals managed to get away as by the fact that she was cheated of a story and that Ed, a male colleague, presumed that she was actually in need of rescuing. Ed had got in her way "by acting the hero. Bloody idiot" (163). Ed's faux pas here is applying normative standards of femininity as the interpretative frame for Maggie's situation "as a female;" despite all the cues that she evinces in her daily behaviour and personality, he is unable to concede - or even acknowledge - Maggie's identification with the powerful codes of masculinity. Maggie's rage is more than the motivation that drives her to investigate - it is also her way of performing masculinity. She does so by giving explicit expression to her outrage such that it becomes a form of political activism as delineated by Halberstam $(1993,189)$. 
Maggie's anger reflects her author's and is part and parcel of Otter's feminist project. Otter's German reviewers, in particular, have emphasised the angry quality of her writing (Krekeler 2013, par. 16, König 2013, par. 4). ${ }^{21}$ When asked by Jonathan Amid what being a feminist means to her, Otter mentions, among other things, her anger. Persistent gender-based injustice, gender-based violence and the slow progress to gender equality make her "furiously angry" (Otter 2014b, par. 45). Maggie is a way for Otter to channel her own rage. Unlike the female perpetrators I have examined, Maggie does not kill, yet the anger that she feels when she faces the perpetrators is within a hair's breadth of fuelling retaliatory murder. Having tracked down Vincent Ndlela, rapist of a baby girl, "[s] he felt the heft of the gun in her hand. Anger iced her veins and her finger hovered on the trigger" (2014a, 243). Similarly, in her confrontation with serial killer John Evans, aka Alex Field, Maggie is wild with rage; she knees him and, training the gun on his face, keeps on kicking him violently with her boots (2016b, 229). Both times, she is stopped by her male allies. In the second incident, it is the police captain Solomon Njima, an unmistakeable representative of the male law, who shouts, "Enough Maggie!" and handcuffs the criminal (229). Defeated as John already is, the act of handcuffing him is superfluous. Handcuffing in this case does not serve the practical purpose of containing a male criminal, but is rather a symbolic act aimed at containing the threat of female violence. After all, Maggie's violent outrage is hard to halt. Female violence, as Halberstam reminds us, contests the coupling of power with masculinity $(1993,191)$, and this is where its threat to hegemonic masculinity lies. The police captain's intervention is also a reminder that Maggie's weapon, as an investigative journalist, is not the gun, but the pen. Maggie's revenge has to stay within the confines of the law. What further distinguishes Maggie's masculine gender performance from that of the female perpetrators is that her rebellion does not lie in "indifference to the law," as Halberstam suggests for her model of female masculinity; hers is rather an open "opposition of the law" $(1998,9)$. Maggie's professional role obliges her first and foremost to engage with the representatives of the male law, be they police or media, ${ }^{22}$ and this means a relentless tug of war. Her open resistance to her superiors causes her to be "called in front of the board and reprimanded" only two weeks into her new job as

21 “'Balthasars Vermächtnis' ist die wütende, schnelle, handkantenharte Ouvertüre für eine hoffentlich lange Serie" (Krekeler 2013, par. 16). "Balthasars Vermächtnis ist ein wütender Roman. Zu Recht" (König 2013, par. 4).

22 Maggie's direct superior in Karkloof Blue is a woman, Tina Naidoo, yet she is entirely compliant with and answerable to an all-male board of directors (93-94). Despite female middle management, The Gazette is still a male-dominated company. 
news editor of The Gazette in Karkloof Blue (2016b, 99). Her bosses repeatedly threaten to take her off the case (Otter 2014a, 40-42, 2016b, 49, 71-72, 77, 82-84, 95). In Balthasar's Gift, she is suspended for two weeks (2014a, 246); in Karkloof $B l u e$, she is explicitly forbidden from writing the case up in the media. In both instances, Maggie continues investigating anyway. However, as she is unable to flout the law, she must now operate covertly.

At this point, it is important to examine how Maggie's gender performance intersects with race. Two strategies are apparent in Otter's novels. First, Maggie's gender performance is characterised not only by an angry masculinity, but by a rejection of (White) femininity. This dis-alignment with White femininity is accompanied by a simultaneous affiliation with Black femininity, especially Black female masculinity. There are a number of ways in which Maggie distances herself from conventional femininity. Maggie is explicit about the fact that she does not have and does not need typically female skills such as arranging flowers and doing small talk at dinner parties (2014a, 113). "[W]omanly pursuits like having their nails done and drinking cappuccinos with their girlfriends at the mall" are outside the range of her interests (2014a, 149-150), and she does not frequent the "sort of restaurant[s] women liked" (2016b, 178). As important as her explicit rejection of the traditionally feminine is her rejection of Afrikaner culture and thus - as a woman - the stereotypical femininity that pertains to this ethnicity. Maggie is called a "renegade Afrikaner" by her boss (2014a, 41), and later on she recounts the very particular experience that turned her into one. The mother of Maggie's school friend Lynn "was too brassy, too blonde, too busty, too lipsticked to fit in with the other tannies" (133). The fact that she was a prostitute, and looked like one, made her and her daughter outcasts in the Afrikaner community (50) and also vulnerable to violence. When Lynn and her mother were murdered by one of her mother's regular clients and it later turned out that he was "one of the dominees from church" (204), ${ }^{23}$ Maggie "turned her back on church, refus[ing] to return. She became a renegade" (204). With Lynn's death, Maggie loses her only ally, as well as all respect for the religion brought to South Africa by her Calvinist forefathers. Her contempt extends to the "self-important buffoons who ruled church and state for so many decades, who pretended that their cause was righteous and found justification for it in the Bible" (261).

Maggie's own mother, by contrast, embodies the ideal of the traditional Afrikaner woman. Unpacking the origins of that ideal, McClintock notes that " $t$ t $]$ he family household was seen as the last bastion beyond British control 
and the cultural power of Afrikaner motherhood was mobilised in the service of white nation-building" $(1995,379)$. All the while, however, women were "denied any formal political power" (379). As a dutiful housewife whose favourite place is the kitchen and who is forever cooking (2014a, 187), Maggie's mother fills the role assigned to her by Afrikaner patriarchy. When her son Christo goes AWOL from the army, she is shamed to the extent that she and her husband have to move away, as they can no longer show their faces in church in Pietermaritzburg (9o). Maggie repudiates everything that her mother embodies and never forgives her for effectively abandoning her and Christo by giving in to the pressures of church. Maggie's female masculinity is thus also a contestation of the kind of religious Afrikaner femininity that her mother represents. By choosing such angry masculinity as a woman, Maggie resonates with and powerfully contests the icon of the volksmoeder, the mother of the Afrikaner people. McClintock discusses this culturally influential social category as manifested in the Vrouemonument (women's monument) that was erected in 1913 in memory of the female victims of the Anglo-Boer War. The monument takes "the form of a circular domestic enclosure, where women stand weeping with their children." In this way, according to McClintock, "women's martial role as fighters and farmers was purged of its indecorously militant potential [...] enshrin[ing] Afrikaner womanhood as neither militant nor political, but as suffering, stoical and self-sacrificing" $(1995,378)$. Maggie's rage, in particular, serves to expose this long-standing containment of women's more assertive and agentive roles.

And yet, while Maggie unambiguously rejects stereotypical Afrikaner femininity, the way in which she simultaneously differentiates herself from the White English-speaking population - this time by means of social class, rather than gender - gives rise to a certain paradox. In many ways, Maggie confirms the stereotype of the strained relationship between Whites of British extraction and White Afrikaners in South Africa, acting out the old enmity between Afrikaner colonialists and British imperialists. Maggie notes a sense of entitlement and self-importance in the comportment of the former pupils of an English-speaking private school (2014a, 71). She, by contrast, "felt no such ownership" (71). This is also the reason for her break-up with Spike. She does not fit in with his family: "She would always be the discordant note, the Afrikaans underclass piercing the bubble of his family's wASP privilege" (2016b, 22). More than once she criticises "the tiny world of the wealthy" into which Spike had briefly introduced her for the fact that even now, post apartheid, they "own everything" $(39,40)$. On the one hand, Maggie's opposition to the White, wealthy population of British descent has the advantage of making visible the differences within White South Africa. Accordingly, the invisibility of 
Whiteness that Dyer criticises, along with its concomitant normative power, is challenged $\left(1988,3^{-4}\right)$ : White, too, becomes a colour. On the other hand, her self-differentiation from Whites of British heritage also positions her more clearly as one of the Afrikaner Whites whose values she contests so forcefully.

At the same time as Maggie distances herself from traditional White Afrikaner femininity, she seeks and finds allies in Black women, especially those of the angry, avenging type. In Balthasar's gift, the most remarkable case in point is Cora Ncube, sister of Pontius Ncube, who was killed by Balthasar's father because he was his son's lover. After Pontius's murder more than a decade earlier, Cora was taken on by the Meiring family "as part of the reparations" to enable her to sustain the Ncube family after Pontius's death (2014a, 217). Cold, tall Cora is silent for most of the novel, until Maggie approaches her and she offers to help the journalist (250). As an invisible insider in the Meiring household, and having waited for her moment all these years, Cora now takes charge over her employer and metes out justice. She rescues Maggie from Lourens's clutches. Knowing that he is about to be exposed, Lourens has set fire to the farm in an attempt to annihilate himself, his wife Sanet and the 11-year-old girl Mbali whom he has been holding captive, as well as Maggie and Cora. “'Stop!' said a voice. In the doorway, holding Meiring's gun [...] was Cora" (264). Cora takes the commander's chair, confronts the Meirings with the facts behind Pontius's murder and identifies Lourens as the murderer of his own son (267). In an apocalyptic scene, she directs Maggie, with Lourens, Sanet and Mbali in their car, to drive through a wall of fire to safety (269-270). Karkloof Blue continues female interracial cooperation by featuring the grown-up Mbali as Maggie's intrepid Black female ally. Mbali now works in the PR department of Sentinel, where Maggie bumps into her: "Fourteen years ago, Mbali Sibanyoni had been a little girl in danger. Now she was a woman in a sleek corporate suit" (34). Initially loyal to her employer, Mbali later becomes instrumental in disclosing the company's criminal activities (233). In the novel's final scene, we learn that Mbali is to be Maggie's new business partner: "Sibanyoni and Cloete would soon be setting up shop in Durban as private investigators" (234). Another openly resistant Black woman in the same novel is Hope Phiri, a scientist and expert on the Karkloof Blue butterfly who speaks out about the ecological damage wrought by Sentinel (130). In an attempt to silence her, Hope is severely beaten up by Sentinel's henchmen, but her resilience and outrage triumph: "A fire burned in her eyes. 'Angry. So fucking angry. If someone gave me a knife and one of those guys, I would murder him with no compunction. [...] And I think I would enjoy it' " (16o). In the end she resorts not to killing, but to reporting the crime to the police despite the criminals' threats (163). 
The way in which Maggie joins forces with angry Black women is reminiscent of Mackenzie's heroine Jade, who similarly aligns herself with Ntombi in Pale Horses. As we have seen, both Jade and Ntombi take the extra step of killing the perpetrators (Mackenzie 2012b, 286). How are we to read this strategy of White female investigators seeking and forging ties with Black women in acts of female masculinity? Speaking about Balthasar's Gift, Otter explains that it was part of her "feminist agenda" to "give voice to the voiceless and agency to those who are usually in the background of other people's lives" (2014b, par. 41). Given the fact that, as women, White authors and White investigators share the plight of patriarchal hegemony with their Black sisters, but, as Whites, are also historically complicit in their subjugation, such an act of "giving voice" must be examined critically. At least potentially, it harbours the danger of reinforcing racial hierarchies. There is evidence for and against such neo-colonial tendencies in Otter's novels. As insistently as Maggie rejects White Afrikaner femininity, she does not explicitly acknowledge White women's complicity in the racist project. McClintock details how "[w]hite women are both colonized and colonizers, ambiguously complicit in the history of African dispossession" $(1995,379)$. While Maggie is insistent about her difference from the wealthy descendants of upper-class English South Africans, she does not recognise her own status as privileged in comparison to that of Black women. She likes to view herself as the saviour, as "the last person still asking questions, a lone light in the dark" (2014a, 215) - albeit with a certain irony at times, as when she calls herself a "self-appointed hero" who "had ridden in on her steel charger to sort things out" (137). ${ }^{24}$ She is plagued by feelings of guilt on several occasions, but these are unrelated to race. Mostly, she feels guilt for not living up to the high moral aims that she sets herself as a saviour and advocate for the disenfranchised - for not having reacted to Balthasar's request for help when he was still alive (2014a, 16), for putting her brother at risk and being unable to protect him (2014a, 246, 2016b, 194), or for endangering Hope (2016b, 130-131). Maggie has a patronising side that is commented on by several characters, but is seldom reflected on by Maggie herself, let alone with regard to race.

Despite her lack of self-reflexivity as regards potential complicity in racism, Maggie's actions and results in both of her cases take a clear stance against White racism and - in Karkloof Blue, in particular - against the injustices committed by White people during apartheid. Importantly, too, Black female masculinity is acknowledged as positive and powerful, rather than erased and

24 She is also reproached for her "saviour complex" by both her brother and her boss, which functions as a qualifier (2016b, 41, 147). 
punished, in both of Otter's novels. This is significant if we recall that Black female masculinity resonates with the racist stereotype of the Black criminal woman. However, Halberstam notes that "there is a difference between racist representations of supposedly failed femininity and a potentially queer or at least subcultural representation of a potent black butchness" (181). Maggie's alignment with Cora, Hope and Mbali is politically effective, but it remains to be seen whether it will develop into a true partnership between Black and White female masculinity that involves more than an occasional ceding of power on the part of the White investigator, as when Maggie hands over control to Cora during the rescue mission in Balthasar's Gift. The fact that the new agency established by Maggie and Mbali is to be called "Sibanyoni and Cloete" (2016b, 234), with Mbali's name featuring first, is a sign that the series may be moving in that direction.

\subsection{Cases of Premature Burials of the Past: the Female Detective as (Contained) Agent of Justice}

True to Otter's resolution, neither of the novels that she has published so far features female corpses. The author has repeatedly stated her discomfort with the sexy female corpse in crime novels, the problematics of which have been exposed by Bronfen (see my discussion of Penny Lorimer's female victims). Otter says that she is tired of this representational practice and finds it dull and disrespectful to women: "I took it as my personal challenge to step up imaginatively and not start a book with the dead, naked, mutilated corpse of a young woman" (2014b, par. 39). As a consequence, all her dead bodies are male, although some still pander to genre expectations. Balthasar, for example, offers a variation on the spectacular death. From a distance, we see his bleeding body through Maggie's eyes, lying on the veranda of Pietermaritzburg's HIV House (Otter 2014a, 11). Together with a group of other onlookers, she witnesses the paramedics' frantic but futile efforts to revive him, while she is simultaneously on the hunt for information to write her story. When she realises that Balthasar was the person who called her a few weeks earlier asking for help in exposing a fake AIDS cure, she asks herself whether "someone [had] to die nowadays to get her attention" (13). Thus, she self-reflexively recalls the media's problematic obsession with spectacular crime. The spectacular in Karkloof Blue lies in the surroundings of the corpse - Howick Falls form an impressive backdrop. What turns out to be Dave Bloom's dead body we see as a mere "slash of white" on the blackened rocks, through the eyes of a passer-by alerted by a pile of clothing at the edge of the falls $(2016 \mathrm{~b}, 9)$. Here again the body functions as a cipher, at least initially. In the case of the seven young freedom fighters, the Umlazi Seven, we witness the ghastly crime itself across time, mainly through the eyes 
of the perpetrators. We do not know who they are as they secretly poison the equally anonymous victims, then burn and bury them deep in the forest (68, 96-97). The mystery is for Maggie and for the police to solve. None of these male dead bodies is entirely without individuality, but they all exemplify Otter's main concern, which lies less with the individual victim than with the structures and systems that he represents - structures that the perpetrators are determined to deny or to conceal. Before we examine those structures, however, it is important to dwell for a moment on the particularities of Maggie's gaze and the kind of spectatorial position that she assumes.

It is striking how frequently Maggie's conflicts with her various superiors revolve around the nature of her, the journalist's, gaze on and relationship to the subject she is writing about. Both Maggie's news editor in Balthasar's Gift, Zacharius, and his predecessor remind her, "Jeez, Maggie [...] the verb is report. You are a reporter. It's not your job to get in there and get your hands dirty" (2014a, 87). "We will report what [the police] say, and only what they say" (40). With this, they stand for "neutral observ[ance]" (174), "objectivity" (174), "professional distance" (95) and "professional indifference" (99), as well as for submission to the state's justice system. Maggie's stance, by contrast, is to relate to the victims, to care for them (87), to identify with them (41). Maggie decides against keeping herself distanced from what she sees; her gaze is an empathic one, and she cannot help but involve herself (91, 99, 174). Her radical refusal to remain objective in the face of injustice is also an ethical stance, in that she will not exempt herself from responsibility by way of distance and refuses to objectify the people she looks at and writes about. Moreover, her position opens up a path for alternative justice. In the light of feminist legal scholars' critique of the seeming neutrality and objectivity of the legal system as adhering to male standards (Van Marle and Bonthuys 2007, 29), as well as their claim that any alternatives to this model must acknowledge a person's relationality to other people - with regard to rights as well as responsibility and culpability (Hudson 2012, 392) - Maggie's decision to get involved appears not as unprofessional, but as principled. In fact, Maggie seems to represent a kind of journalism that takes seriously the affective dimension of communication. Lelia Green and Steven Maras maintain that impartial objectivity in journalism is an illusion $(2002,19)$. As the former ВвС correspondent Martin Bell puts it, there is "nothing object-like about the relationship between the reporter and the event" (24). On this basis, Green and Maras advocate a journalism that acknowledges (both the journalist's and the reader's) affectivity in ethical ways, without neglecting the media's established "responsibilities concerning democracy, the provision of information, informed debate, and accuracy" (28). 
In Karkloof Blue, in particular, Otter challenges the idea of journalistic objectivity and detachment and emphasises the need to adopt different principles. On the one hand, it is impossible for Maggie to remain an emotionally distanced onlooker when one of the murder victims in the novel is her own brother, Christo. On the other, the media's involvement in broader power structures is exposed, giving the lie to the notion of media impartiality. Formerly "snuggled up to the City Hall and the courts complex" (2014a, 202), the Gazette's offices have been relocated to an office park on the outskirts of Pietermaritzburg $(2016 \mathrm{~b}, 14)$, close to Sentinel's corporate headquarters (33). Corporate interference is rife. As neighbours and paper suppliers, Sentinel are able to exert direct influence over the Gazette's board members and journalists $(77,83)$. In addition, they secretly infiltrate the news team with a spy (204), all for the purpose of camouflaging their criminal activities and allies. Controlled by criminals, such journalism becomes complicit and devoid of justice. Even though Maggie battles against it, her own journalistic endeavours, too, endanger a life. In an attempt to raise public awareness of Sentinel's ecological crimes, she quotes Hope, the biologist, who is subsequently targeted by the criminals and nearly killed. Here journalism, even of the responsible kind, is depicted as a double-edged sword in the fight for justice. Maggie's final move out of journalism at the end of Karkloof Blue, when she decides to become a private investigator, is consistent with her determination to combat injustice, but even this does not render her entirely free of the media frame: the agency's first case, she tells us, will be paid for by a newspaper, the Joburg Sun (234).

In Balthasar's Gift, Maggie exposes the slow but devastating violence of South Africa's AIDS pandemic, highlighting its strongly gendered and racialised components. The homosexual Afrikaner AIDS activist Balthasar is killed by his own father, Lourens, who fears having to admit his own HIV positive status. Balthasar, rejected by his father for his sexual orientation, is the only person who knows that his father is HIV positive. He also knows that his father did not kill his lover Pontius in self-defence all those years ago. Using this leverage over his father to pressurise him into confessing his HIV status and his infidelity to his mother is what gets Balthasar killed. The underlying reason for his murder is thus HIV/AIDS denialism, as well as denialism in relation to homosexuality. While investigating Lourens's crime, Maggie also brings to light the larger crime of then South African president Thabo Mbeki's AIDs denialism. Mbeki and his Department of Health - both in the novel and in reality - denied that HIV actually causes AIDS. They also questioned antiretrovirals (ARVs) as an effective antidote, claiming they were toxic (Otter 2014a, 227, Decoteau 2013,144 ). This attitude let the virus spread unabated and contributed to the deaths of almost half a million South Africans at the turn of the millennium 
(Decoteau 2013, 144). With the help of key figures such as Lindiwe Dlamini, the head of the AIDs mission, who used to work with Balthasar, Nkosazana Mbanjwa, who looks after the children in Balthasar's private orphanage, and elevenyear-old Mbali, the eldest of the children in Balthasar's care, Maggie is able to document the multitudinous ways in which those affected with the virus and their families suffer. These include stigmatisation and grief (Otter 2014a, 92, 78, 135); children being raised by grandparents and siblings in the absence of parents (92, 94, 139-140, 188); baby rape (93); mother-to-child transfer of the virus and the concomitant diseases affecting everybody, including babies and small children, once they develop AIDS (99-102, 226); denialism on the part of men, who refuse to be tested $(179,192)$; exacerbation of poverty (6o); and erosion of communities (124). Maggie's investigation renders visible the unspectacular, systemic forms of violence ensuing from the AIDS crisis and puts at the centre its victims, mostly marginalised people of colour, who are forgotten by the government (184). In Hudson's terms, Maggie's fictional justice consists of accommodating, of bringing in those who are "outside the constituency of justice" (Hudson 2012, 389): "Balthasar's constituency, the hundreds and thousands of people with AIDS and no recourse to life-saving drugs" (Otter 2014a, 202). What is more, Maggie serves reflective justice, insofar as she draws attention to structural forms of violence, normally inadmissible in the formal criminal justice system (Hudson 2012, 393). Besides portraying the effect of the government's denialism, the novel shows how it facilitates crimes such as the rape of babies and the fake AIDS cure industry. The government's claim that ARVs are toxic is depicted as playing into the hands of criminal business people and as furthering exploitation of the most vulnerable. Maggie attends a court session in the case against Dr Schloegel, a German selling a fake AIDs cure. When asked by the judge why she spent large sums of money on Schloegel's vitamins rather than on ARVs, the mother, whose son has since died, replies: “'We were told they made people sick.' " Maggie fumes, "This rumour had gone from a whisper to a rumble. If the government didn't trust the medication enough to make it universally available, then people didn't trust it either" (Otter 2014a, 59). In the course of her investigation, Maggie uncovers a whole network of criminals behind this travesty: "[A]s a crime lord you fed AIDs victims a cure that potentially hastened their deaths, or at the very least did nothing to obviate it, then you lent the grieving families thousands of rands to hold a funeral. When they couldn't pay you back, you turned them into Schloegel's Herbals salespeople. And the money just kept on rolling in" (197). Moreover, the government's attitude fosters myths like "sex with a virgin will cure HIV" (228), and therefore " $\mathrm{r}]$ ape of both women and children is part and parcel of the spreading of HIV" (229). 
Alongside the South African government, Otter's novel features another, individual, AIDS denialist: the murderer Lourens. This staunchly religious Afrikaner patriarch hushes up the fact that he is HIV positive. His status, which is the result of extramarital sex, is incompatible with the religious beliefs that he purports to uphold: "It burnt his soul, this responsibility to tell his wife. It was admitting failure, a weakness. The crack in the dam" (170). This makes it easier for him to remain blind to his own role in contracting the disease and instead to put the blame on the women he had sex with (170) and to denounce the HIV virus as something "evil" brought to "the innocent" by homosexuals from overseas (104). Thabo Mbeki's reasoning behind his denialist stance - which is not touched on in the novel - reveals a similar distancing of Africa from the rest of the world. According to Posel, Mbeki insisted that "AIDS in Africa was different from AIDs in the West." In Mbeki's view, AIDs in Africa "was a primarily heterosexual epidemic [...] unlike the largely homosexual incidence of AIDS in the West" (Posel 2008, 16). Because Western experience cannot be superimposed on African reality (16), ARvs come to be seen as un-African (18). ${ }^{25}$ Otter, who locates Balthasar's first homosexual relationship - with Pontius - in South Africa itself, and who has him travel to Europe, work there in a hospital, see his partner Stephen die and come back to South Africa healthy and with a mission to help those with AIDS (2014a, 27, 54, 265), contests Mbeki's and Lourens's trajectory of differentiating themselves from the evil and homosexuality in the "West".

As well as rejecting the claim that AIDS and sexuality are fundamentally different in Europe and Africa, Otter repudiates the notion of a radical break between the apartheid past and post-apartheid present, as invoked by Mbeki in his rhetoric portraying the new South Africa as a nation reborn from a wretched past (Posel 2008, 19). Repeatedly, Otter draws parallels between the horrors of the AIDS crisis and the horrors of apartheid: then and now, a high death toll among children and young people (2014a, 143, 145); then and now, children raised by their grandparents (188); then and now, rape as a tool of war (229). Otter's depiction of the crime of denialism in South Africa, "one of the

25 Posel explains the controversy surrounding the nature of HIV/AIDS during Mbeki's presidency with reference to the "symbolic politics of the 'new' South Africa in transition from the horrors of apartheid" $(2008,18)$, linking Mbeki's AIDs denialism with his promotion of an African Renaissance as the basis for his nation-building project. According to Posel, the imagery of sexuality that Mbeki associates with orthodox understandings of HIV/ AIDS evokes "the spectre of the past: the colonial nightmare that imprisoned the black mind, enslaved the black body and degraded the pursuit of pleasure. It is exactly that which the African Renaissance has to vanquish: the demon within 'our African selves' " (Posel 2011, 142). 
few developing countries with the resources to have made a significant dent in the epidemic if it had acted concertedly and unambiguously" (Posel 2008, 18), can also be considered a symbolic move towards doing justice to those directly or indirectly afflicted by the disease, especially Black women living in poverty. Given that those who suffer most from HIV/AIDS are Black women, the consequences of any form of denialism have a gender and race dimension (Otter 2014a, 179, 228-229). According to the AIDS Foundation South Africa, "South Africa has the highest prevalence of HIV/AIDS compared to any other country in the world with 5.6 million people living with HIV. [...] Women face a greater risk of HIV infection. [...] The difference is greatest in the 15 to 24 age group, where three young women for every one young man are infected" (2017, par. 1-5). Adding the category of race, Albertyn argues that HIV/AIDs has further entrenched inequality, especially for Black women: "Women bear the greatest social and financial burden of domestic and caring work, especially in the context of the AIDS pandemic. Gender inequalities mean that women are more vulnerable to HIV than men, infected in higher numbers, and at a younger age" (Albertyn 2007, 82). The fictional empowerment of Black women such as Cora, Nkosazana and, most significantly, young Mbali becomes all the more significant in the light of these depressing realities. By using and satisfying the crime genre's preference for spectacular, event-based violence in order to bring into focus the underlying structural violence of the AIDS pandemic and its gendered and racial aspects, Otter, much like Lorimer, successfully establishes the power of popular fiction as a form of "currency" for the dissemination of these truths.

Maggie's case in Karkloof Blue again highlights the impact of violent structures and the links between South Africa's past and present. The novel features various crimes against human beings and the natural world. All of them revolve around the Pietermaritzburg-based forestry company Sentinel. The murder of Dave Bloom, a long-time Sentinel employee, was instigated by Xolani Mpondo, the company's current CEO. When Dave realised that one of his colleagues was doing research into biological weapons, he threatened Xolani with exposure unless he stopped logging the Karkloof forest, natural habitat of the endangered Karkloof Blue butterfly (Otter 2016b, 233). Maggie's brother Christo also dies because he knows too much. He finds out that Xolani has been paying hush money to John Evans, aka Alex Field, so he is killed by John. John knows about Sentinel's secret laboratory, which goes back to the apartheid era, when he was a security policeman working for a unit that experimented in biological warfare. Moreover, in the 1980s, John was responsible for killing the Umlazi Seven, a group of young ANC freedom fighters who were believed to have blown up a power station. After they had been poisoned with anthrax-laced 
food, their bodies were burnt and buried in the Karkloof forest by John and his helpers $(207,227-228,230)$. This secret killing in the past is the reason that John launches a militant campaign, supposedly fuelled by ecological concern, against Sentinel when they announce plans to log the Karkloof Forest - home to both the butterfly and the apartheid grave. Dave's murder thus simultaneously leads Maggie to present-day corporate and ecological crimes and returns her to apartheid crimes, as old bones are dug up in the Karkloof forest.

What are the implications of this explicit link between the violent apartheid days of the 1980s and the equally violent times in South Africa's young democracy 30 years later? What Otter is painting here is a picture of continuity that questions notions of radical change between the two different eras in the country's history. Sentinel's "lab within the lab" has always been used for research into biological weapons (168) and has always been a destructive tool of war. Sentinel's obsession with making profits and past and present governments' demand for weapons have led to a collaboration beneficial to both sides. Maggie learns that in the old days Sentinel's director "was offering certain high-up members of the government [their] research facilities in return for favours. [...] Access to land that Sentinel could turn into plantations, logging permits, fewer obstacles in buying up pristine grasslands" (168). The present government, too, is interested in Sentinel's research (233). However, to realise the immanent violence of structures, it takes people. Given the inherent power of the structures, the individual actors may change - both the government and Sentinel's CEO are new - but their interactions with the structures will lead to similar violent results. What is more, the agents of the old days are still alive, as is their knowledge and their interest in protecting themselves from exposure. John chose to conceal his actions and never asked for amnesty during the TRC hearings (231). His helpers, Chief Mjoli and Mandla Cele, also "want to bury the past" (157, see also 230). Both sides violently oppose Maggie's probing into this complex web of collaboration and complicity that crosses not only colour lines, but gender lines. The researcher who runs Sentinel's secret lab is Susannah Hynde, while Sentinel's main ally at The Gazette is the editor Tina Naidoo. The agency of these two women contributes significantly to the crimes that are committed.

Posel and Simpson argue that it is necessary for complex truths, "moral ambiguities born of the politics of complicity or collaboration," to emerge if we are to process and understand the past $(2002,10)$. Enfolding multiple layers of agency as it does, Otter's novel illustrates the value of crime fiction as a site where past and present complexities can be explored. Depicting the perpetrators' interaction with the structures is a further necessity in this process, according to Posel, as it allows insight into the causes of past violence and may help to transcend it (168). Otter's fictional version of the past reveals various 
causes for such interaction. Sentinel's former manager shared the racist ideology of the apartheid government, but he was also very keen to further his business. Falling paper prices forced him to find new land for more plantations, so good relations with the government were useful (2016b, 167). John, as a secret policeman and spymaster, was clearly a henchman of the apartheid government. We can infer that his motives were ideological. His Black accomplices opposed the government, but disliked the violent resistance of the Umlazi Seven. Instead, they chose "a middle route, a dangerous straddling of two worlds that pays now" (96). Although Otter's fictional apartheid crimes are motivated as much by racism as they are by opportunism and greed, it is the latter that fuel crime in the democratic era, supported by criminal structures that survived the end of apartheid. The persistent crimes to which corporate greed, in particular, leads are illustrated succinctly: destruction of natural forest, the country's natural heritage (10) - including trees, all the other plants that grow there, rich soil and animal life $(33,63)$ - erosion and water shortages (64), pollution of the environment and damage to the health of paper mill workers caused by the chemicals used in paper production (167), as well as retrenchment of workers without compensation (211).

It is interesting to note that Mackenzie's most recent novel, Bad Seeds (2017), follows a very similar course. The violent structure that Mackenzie's novel exposes is a nuclear research centre, used for nuclear warfare then and now. As in Karkloof Blue, the main agents have changed with the onset of democracy, but those formerly in power continue to exert influence. In this respect, both authors seem to agree with Anthony Butler that "[t]he institutional executors of apartheid - in business, the media, the judiciary, and the universities - avoided admission of (and so reflection upon) their own culpability" $(2009,53)$ before the TRC. While Mackenzie's novel frames the South African present in terms of the latent threat of present and future international terrorism, in Karkloof Blue Otter depicts the present as still heavily influenced by the past. She generates a strong impression that not enough justice has been done with regard to South Africa's apartheid past and explicitly refers to the work of the TRC. As Maggie reflects,

South Africa had a history of secrets, buried under the weight of second chances. In their rush to reconcile under the rainbow banner, the government had given those who'd confessed to apartheid-era crimes their own walk to freedom. During the Truth and Reconciliation Commission, many of their secret crimes had been unearthed, but there were hundreds of families still living without knowing what the apartheid state had done to their loved ones. [...] Peace had been achieved, but not justice.

OTTER 2O16b, 91 
By returning to these "secret crimes" in her crime fiction, Otter aims to provide an imaginary space to continue and complement the work of the TRC. When Maggie listens to Thandi Mshenge and seeks to establish the identity of the bodies in the mass grave in the forest, she caters to a perceived need to unearth more secrets than the TRC was able to uncover. Maggie works to restore the respect that is due to the families of the victims by providing knowledge about what happened, holding the perpetrators accountable and giving the relatives a body to bury. This allows for a reintegration of their losses into their lives and for closure. Given the necessarily incomplete achievements of any truth commission, crime fiction takes on a remedial role. In their reflections on the TRC, Hamber and Wilson touch on what Maggie calls the "rush to reconcile". They note that " $[\mathrm{t}]$ ruth commissions often operate on a time frame which is highly curtailed and limited, and which requires a premature process of dealing with the past from survivors of atrocities for whom the process of grieving often lasts a lifetime" $(2002,36)$. Literature can prolong and continue a truth commission's limited frame. This is particularly true for crime fiction, the genre that serially uncovers the past in order to account for the present.

For Otter, the key figure in this endeavour is not the victim, but her female detective, who, as a journalist, becomes the victim's advocate in the public space of the media and, thanks to this power, guides the police and can serve as their corrective. Maggie has close ties to the police throughout both novels. In Balthasar's Gift, she has the police liaison officer, Thandi Mathonsi, who briefs her daily, on speed dial (2014a, 9): "Tall and clever, she had an attitude as sharp as her designer spectacles and knew how to keep a journalist's appetite for more satiated without stepping outside her political boundaries" (2014a, 14). Maggie retains good relations with the police in Karkloof Blue through Solomon, the police captain, who develops a love interest in her. Yet all the while, Maggie is not uncritical of the police. She knows that they are insufficiently resourced and do not always have the best reputation $(2016 \mathrm{~b}, 149,182)$ and she repeatedly questions the police's versions of the crimes she is faced with. For example, she can prove that Balthasar's death is not a "a robbery gone wrong," as the police claim $(2014 \mathrm{a}, 14)$, and nor is Dave's a "suicide" (2016b, 55). At the end of both novels, she personally hands over the perpetrators to the police and to state justice (2014a, 254, 270, 2016b, 225-229), either by delivering them directly into the hands of the police (Lourens) or by leading the police to the place where they are hiding (John). In Karkloof Blue, the narrator describes how, with back-up stationed at the edge of the forest, "Njima, Rankin, Maggie and three constables walked the path to Karkloof Extension 7. [...] When they reached the chosen spot, Sol and his team stayed back and Maggie walked on by herself' (2016b, 225, my emphasis). Maggie confronts and defeats John the 
armed serial murderer single-handedly (2016b, 229). Only then does the police captain step in to arrest him. In a country where the criminal justice system is both inefficient and distrusted, resorting to investigative journalism as an alternative means to deliver justice seems reasonable. It is also actually practised in the contemporary South African real, as Antony Altbeker's true-crime account Fruit of a Poisoned Tree (2010) shows.

In line with her feminist mission, Otter substantially empowers her female detective to function as a necessary corrective to the police. However, there is an element of idealisation in her depiction of Maggie as acting without opposition from the police, while the absence of gender criticism of the institution itself elides the gender complexities inherent in this relationship. This contradiction in a feminist detective novel is further underlined by Karkloof Blue's ending, which is basically a reinstatement of the patriarchal frame and an effacement of the female detective's work. The novel's last chapter features crime reporter Menzi Gumede's article in The Gazette entitled "Mass Graves Apartheid-Era Deaths Explained" (2016b, 230-231), which publishes Maggie's findings and states that formal justice has been served. The media is given the last word, but Maggie has no voice. The epilogue also renders Maggie and her female "supporters in justice" invisible. Maggie is shown attending the funeral of the seven freedom fighters:

Beautiful singing filled the tent. Women's and men's voices entwined in spirals rising up into the sky in sorrow and in thanks as guards of soldiers, dressed in Defence Force fatigues, carried in seven coffins and placed them, tenderly, respectfully, on seven tables. The guards moved to the sides of the tent, standing formally to attention. [...] When the singing stopped, a man got up to speak.

OTTER 2O16b, 232

The man is the provincial premier, who delivers a speech in honour of the dead. The Umlazi Seven are given a belated but formal acknowledgement of their part in the struggle by a representative of the state. A certain kind of restorative justice is served, as they are finally returned by the state's soldiers to their families $(2016 \mathrm{~b}, 234)$ and are included in the nation's memory. What is surprising, however, is that the premier emphasises that it is "through the work of the police" that the families can now bury their sons (2016b, 232), while failing to mention the women who guided the police. The roles of both Thandi Mshenge, the sister of one of the dead teenagers, and Maggie go entirely unnoticed and unacknowledged by male, official South Africa. It was Thandi, distrustful of the police, who alerted Maggie to the possibility that one of the 
bodies found in Karkloof forest might be her brother's, and it was Maggie who pressured the police to follow up (2016b, 78-81) and who identified the web of perpetrators. In order to demonstrate the power and justice of the state, the female agency it depends on is elided completely. In the absence of any artful reminder, be it by Maggie or by the narrator, that qualifies such discursive violence towards women, the novel here effectively performs a patriarchal backlash against women, as Otter recasts her powerful, angry and effective female detective as a humble, invisible servant of the patriarchal law. One can only speculate as to whether the author is making a sardonic comment on the power of the status quo here. In any case, the episode is an illustration of the conflicting constraints to which the figure of the female detective finds herself subjected. The fact that Maggie gets Thandi's acknowledgement in the form of a "small smile and a nod" as she follows her brother's coffin does little to remedy this situation. The epilogue offers the closure required by the genre, as not only are the Umlazi Seven buried with dignity, but Sentinel gets a "newstyle CEO" who closes down the company's secret lab and pledges to preserve Karkloof forest (233). At the same time, however, it also closes over the space previously opened up for Black and White female masculinity.

Otter's headstrong and fearless heroine speaks to a continued need for truth-finding beyond the confines of the present and the constituencies of the privileged. As an investigative journalist, she focuses on cases whose existence is denied or that are prematurely closed by official South Africa, leaving the victims without recognition and justice: AIDs denialism under Thabo Mbeki's presidency, as well as crimes committed under apartheid. Maggie's role vis-àvis the state's justice system is corrective and remedial rather than radically resistant. The justice that she dispenses ultimately remains within the realm of the law, but by foregrounding structural violence that goes unnoticed by the law, by bringing to the centre those who are marginalised by the law, she shapes an understanding of the law as a more inclusive discursive space. As an angry, determined female journalist who looks like a butch, fights like a man, involves herself emotionally, exposes the media's potential for criminal complicity, repudiates traditional Afrikaner femininity and finds powerful allies in angry Black women, she herself changes the face of justice. And yet, neither the White woman Maggie nor the Black women Cora, Hope, Mbali and Thandi whom Otter invests with significant agency and envisages as agents of improved justice question or challenge the legal frame as such. While their powerful actions do not go entirely unnoticed and are validated by success, Karkloof Blue ends with the institutional frames firmly in place and firmly male. Justice is served as formerly disregarded or secret crimes and criminals are now identified and held accountable, but the female agency behind this act 
of justice is effaced. The ending of Otter's second novel functions to contain the female masculinity that she has been celebrating and blunts the force of what would otherwise be a powerful feminist intervention.

A woman who investigates always reveals truths about her criminal cases, as well as about the institution from which she operates. With regard to the latter, Walton and Jones note that "feminist detective novels in general, explore - and exploit - the possibilities of individual agency even as they expose the limitations of that agency. In the process they convey to their audience, especially women readers, both a sense of potential empowerment and a consciousness of systemic oppression" (1999, 208). The three female detectives examined here confirm this observation. As a police detective, Persy Jonas brings out the gendered nature of the police and faces a patriarchal backlash as an empowered Coloured woman. In a similar vein, the investigative journalists Vee Johnson and Maggie Cloete leave no doubt about the - mostly White - male hegemony that dominates their newspapers. In the face of these stifling constraints, they all find remarkably effective spaces for resistance, and in this respect they are figures of female empowerment and agents of gender justice. Their resistant strategies include the solidaristic yet agonistic negotiation of forced choices between Persy and Marge, the recalibration of interracial power relations, as well as combining detective with sexual agency, in the case of Vee, and Maggie's angry female masculinity. Persy's and Maggie's tactics, in particular, also create possibilities for powerful female interracial cooperation and alignment. At the same time, however, the female detectives are undone as empowered agents. Although the patriarchal structures are exposed, they still contain, resist and sometimes even efface the women's agency as detectives. Overall, the institutional frame of the media seems to offer more leeway to women than that of the police. While Persy is not only denied institutional recognition at the end of the second novel, but expelled, Vee and Maggie see their investigative success acknowledged, albeit in attenuated ways. The police receive the credit for Maggie's work, while Vee's success is dampened by the realisation that she has been complicit in Xoliswa's suicide.

For Vee, the main obstacle is not so much the gendered nature of the media frame as the media's partiality and the fact that, as a journalist, she is prone to being instrumentalised. Maggie, too, finds that her newspaper, The Gazette, is increasingly being manipulated by criminal corporate interests. Golakai's and Otter's detective novels thus constitute reflections on the limits of investigative 
journalism within the justice process. This is noteworthy in light of the close relationship that exists between journalism and crime writing in South Africa. A number of the authors whose crime novels feature in this study - Nicol, Mackenzie, Orford and Otter - are or used to be journalists themselves. The same is true of many detective protagonists: Lorimer's Nix Mniki and Orford's Clare Hart are journalists, like Vee and Maggie. What is more, on the South African book market crime novels face serious competition from non-fictional, so-called "true-crime" books (also called "literary/creative non-fiction") based on investigative journalism. De Kock reads both crime fiction and non-fiction works of true crime as expressions of what he terms the "plot loss" that followed South Africa's transition to democracy $(2016 \mathrm{a}, 3)$. For him, they have the same function: they are investigations "into the causes of the perceived inversion, or perversion, of the country's reimagined destiny, a derailing that has widely come to be regarded as criminal" (4). ${ }^{26}$ I will return to crime fiction and non-fiction in the conclusion to this study. For now, it is sufficient to note how heavily invested in real crime the detectives discussed here are. The real referents are always present in the fictional crimes that they bring to the fore, and this is precisely what makes their investigations so valuable as social criticism.

What is striking about the female investigators is how they contest, critique, correct or remedy official truths established by the dominant order, be it represented by the police, the courts or the TRC. Both Maggie and Vee disprove police versions of the official record. Persy and Vee reopen cold cases, revealing new truths and revising existing ones. Maggie and Persy return to old cases that were disposed of too quickly or subjected to insufficient scrutiny at the time, thus correcting and complementing officially recognised truths. They warn against haste in transition, persuading us to look at the past again or to see the present differently. They act against forgetting, and their unrelenting insistence on truth functions as a constant reminder of the law's hegemonic tendencies and restricted ability to serve justice as a broad human good. It is true that Rowe, Golakai and Otter repeat some colonial, racist or misogynist practices and that, as agents of the justice system, their heroines become complicit with this system even as they expose its bias. Nevertheless, by exploring alternatives to "white man's justice" (Hudson 2012, 384), these novelists move beyond a mere critique of the established system. They adhere to the principle of discursiveness by allowing access to justice to those most vulnerable, forgotten or shunned by society - ungrievable lives, in Judith Butler's terminology

26 Earlier contributors to the debate include Hedley Twidle (2012), Mike Nicol (2013b) and Anneke Rautenbach (2013). 
(2010): AIDS victims, isolated teenage daughters, orphans, street children, parents looking for their missing children, secretly buried freedom fighters. Exposing complex relations of dependency and complicity between individuals and the interaction between individuals and structures means taking into account the principle of relationality. Reflectiveness is involved when the categories that define what constitutes a crime, or what violations are susceptible to legal judgement, are amplified in order to include long-term structural violence. By having their protagonists strive for a more inclusive kind of justice - in terms of both gender and race - Rowe's, Golakai's and Otter's novels take a political stance and imagine a possible change to the face of justice. 